\title{
ヒトの臼雪咬合面形態と補綴学的平面との関係について
}

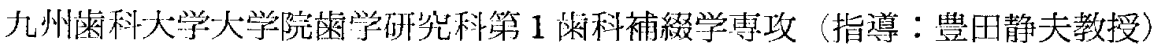 \\ 笋本満雄
}

(本論文の要旨は, 昭和 49 年 5 月 25 日, 第 34 回九州霜科学会総会, 11 月 16 日, 第61回日本補経歯科学会総 会, 昭和50年 5 月24日, 第35回九州崡科学会総会, および11月28日, 九州歯科学会例会において発表した。)

\section{Studies on Relation between Form of Occlusal Surface at Human Posterior Teeth and Prosthetic Plane}

\author{
By
}

Mitsuo Kishimoto

First Department of Prosthetic Dentistry (Director : Prof. Shizuo Toyoda)

Kyushu Dental College, Kitakyushu, Japan

In order to make clear the significance of occlusal form in the masticatory system and make the standard of occlusal restoration, the author investigated the form of occlusal surface of posterior teeth to the prosthetic plane which included the lowest point of left ala of nose and the lowest point of left and right external auditory meatus. Forty subjects who had normal occlusion, 11 males and 29 females, with a mean age of 18.6 years, were included in this study. Formcorder and $\mathrm{X}-\mathrm{Y}$ Recorder were used as a measuring apparatus for this study, and the following results were obtained.

(1) For the mesial and the distal inclined plane of cusp and the total occlusal surface of posterior tooth, the sizes of these projective areas to the prosthetic plane were decreased in the following order. They were first molar, second molar, first premolar and second premolar in the case of upper jaw, while for lower jaw, the order was first molar, second molar, second premolar and first premolar.

(2) A significant difference below $5 \%$ significance level was not recognized between the projective area of mesial and distal inclined plane of cusp in the arrangement of upper posterior teeth. But in the arrangement of lower posterior teeth, the projective area of distal inclined plane was bigger than that of mesial, and the difference of projective area was $14.40 \mathrm{~mm}^{2}$ in the case of male and $14.07 \mathrm{~mm}^{2}$ in the case of female respectively.

(3) The triangular ridge inclination to the prosthetic plane became bigger in the direction of posterior tooth in the stamp cusp, but the triangular ridge inclination of molar was smaller than that of premolar in the shearing cusp.

(4) The open angle made by the buccal and the lingual triangular ridge was 103 $108^{\circ}$ in upper premolars, $111 \sim 125^{\circ}$ in upper molars, $124^{\circ}$ in lower second premolar and $111 \sim 127^{\circ}$ in lower molars.

(5) The line from the incisal edge of lower central incisor to distobuccal cusp tip of 
lower second molar in male and the line from that to distolingual cusp tip of lower second molar in female were parallel with the prosthetic plane extremely. These two lines and the prosthetic plane converged anteriorly.

(6) After measuring the greatest buccolingual tooth dimension and intercuspal distance, the order of these size in each tooth was nearly same as the order of size in the projective area of inclined plane.

(7) The ratio of intercuspal distance to the greatest buccolingual tooth dimension was about $48 \sim 66 \%$ in upper jaw, and about $45 \sim 58 \%$ in lower jaw.

目次

$\begin{array}{lll}\mathrm{A} & \text { 緒 } \\ \mathrm{B} & \text { 被検者および測定用模型 }\end{array}$

I 被 検 者

III測定用模型

C 測定方法

I. 咬頭斜面の補緅学的平面に刘する投射面積

II 三角隆線の補綴学的平面に対する傾斜角度および 咬頭展開角度

III歯牙各咬頭頂の補経学的平面に対する位置

IV 歯冠煩舌的最大幅径および咬頭頂間距離

$\mathrm{V}$ 統計的取り扱い

$D$ 測 定結果

I 咬頭斜面の補経学的平面に対する投射面積

II 三角隆線の補経学的平面に対する倾斜角度および 咬頭展開角度

III崡牙各咬頭頂の補経学的平面に対する位置

IV 菌冠煩舌的最大幅径および咬頭頂間距離

E 考 察

F 結 論

引用文献

\section{A 緒言}

函科補綴学の目的は，失なわれた歯牙に対して正常な 形態と機能とを回復することであり，また残存組織を保 護するととである。

形態を補経学的に回復する場合, 天然菌の形態が大い に参考になることはいらまでもない，特に目曾部の咬合 面形態は，咀嚼機能の遂行，咬合圧（咀嚼圧）の負担， および顎運動との調和からみて，合目的的な形態をして いると考えられる．事実，曰歯部の菊列および咬合面の 形態は咀嚼運動と密接に関係し，口腔買系 ${ }^{1) ， す な わ ち ~}$ 顎骨，䫟関節，䨑牙支持組織，筋神経系，おうよび血管系 の協調的相互作用により形成されるものであり，てれま
でにも咬合面形態を咀嚼能率，咬合圧（咀嚼圧），硕運 動と関連づけた数多くの研究が報告されている。

著者は咀嚼機構の中で占める目霜部咬合面形態の意義 を明確に把握するために，また正常者の標準値を得て咬 合面形態回復の生物学的基準とするために, 補綴学的平 面を基準として，天然歯の臼霜部咬合面形態を詳細に観 察したので報告する。

\section{B 被検者および測定用模型}

\section{I 被 検 者}

被検者は，永久茵列が安定したと思われる15才以上の 男女で，いわゆる個性正常咬合を有する者である（15才 ３0才，平均年泠 18.6 才）. 調查総数 5,364 名中より 40 名（男性11名，女性29名）を被検者としたが，選別は宮 村（1971 $)^{2)}$ の基準を中心にして行なった。

a . 全身状態が健康で, 顎関節, 咀嚼筋群に現症およ び既往症のないもの.

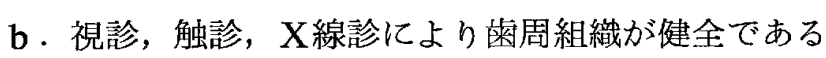
と喼められるもの.

c . 先天性欠如齒, 未萌出歯, 欠損曾, 奇形雬, 過剩 菌のないもの(智䨑は例外).

d. 㐘牙の著しい捻転, 転移, 傾斜のないもの.

e. 万蝕, 充填物, 歯冠補綴物のないもの（1 度のう 蝕, 5 級充塓物は例外）.

f . 咬頭嵌合位が明確で, 下顎運動野に異常のないも の.

$\mathrm{g}$. 開咬, 切端咬合, 過蓋咬合, 反対咬合, 正中離開 のないもの.

h. 全霜牙が正常な接触点関係を有するもの.

i . 咬耗は，咬頭，エナメル質に限られているもの で，栃原 $(1957)^{3)}$ の分類では $1^{\circ} \mathrm{b}$ までのもの.

j. 矯正治療の既往歴のないもの.

II 測定用模型

まず，アルジネート印象材による概形印象から，普通 
石旁模型を製作した，つぎに，苜赾部にスペーサーとし てバイトワックス（厚さ $1 \mathrm{~mm}$ ) を圧接し，才ストロン (GC社) で上下顎とも馬蹄型の個人トレーを製作し

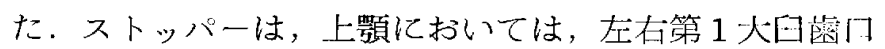
蓋側および切歯乳頭部の粘膜上に，下顎においては，左

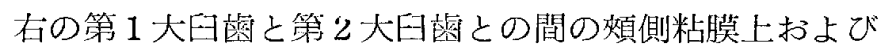
切菌部舌側粘膜上に製作した。校合面の正確な印象を得 るため，ストッパーを陵合面上に製作しなかった。トレ 一は, オストロンの隹み, 応力変形在考慮して, 製作後 24時間以上絽過したもの便用した。

ついで,シュールフレックス Fレギュラータイプ (G C社）による精密印象を行なった。トレーと印象材との 接着には，泥状圭重合の常温重合レジンを使用した ${ }^{4}$ 。

印象撤上後，直ちにシュールストーン（GC社）在润: 人し，乙れを24時間放笡した後，普通不高で台を製作 し，硬化後トレーと不瓷模型とを分離した。

つぎに，Fig. 1，2 に示すように，一部收良した坪 根式顔曰とガラス板（担ガラス $\mathrm{KK}$ ，擪さ $6 \mathrm{~mm}$ ）とを 使用して，上硕模型基底面在補経兴的西面（分側鼻翼外 側下縁点と雨側外耳導口下縁点と含屯平面)に一致さ せた。

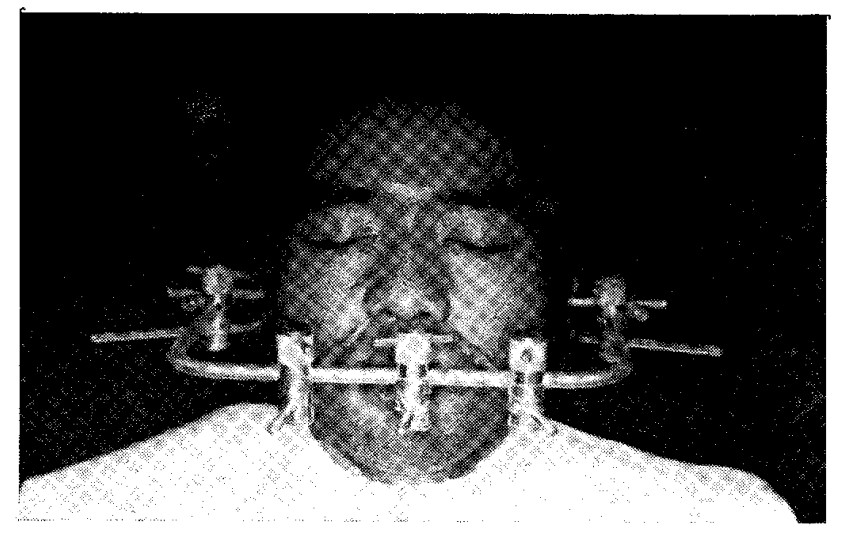

Fig.1 Face bow.

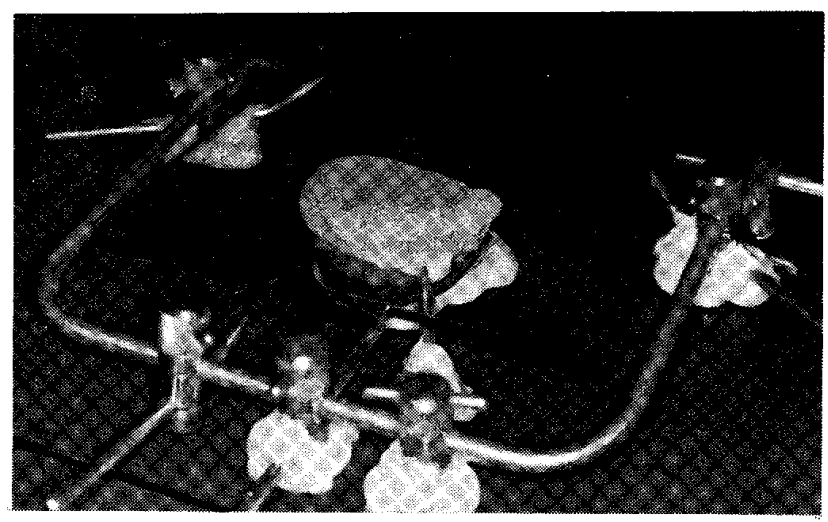

Fig.2 Making base of upper model.
使用したガラス板の真直度，平行度5)を形状測定器( 小叹研究所， E F-1 型) (Fig. 3) と X-Yレコー ダー（渡巡測器製作所, WX-132）（Fig. 4) とを使 用して調べたとてろ，両面ともに真直度 $0.03 \mathrm{~mm} / 100$ $\mathrm{mm}$, 闭面の平行度は $0.03 \mathrm{~mm} / 100 \mathrm{~mm}$ であった.

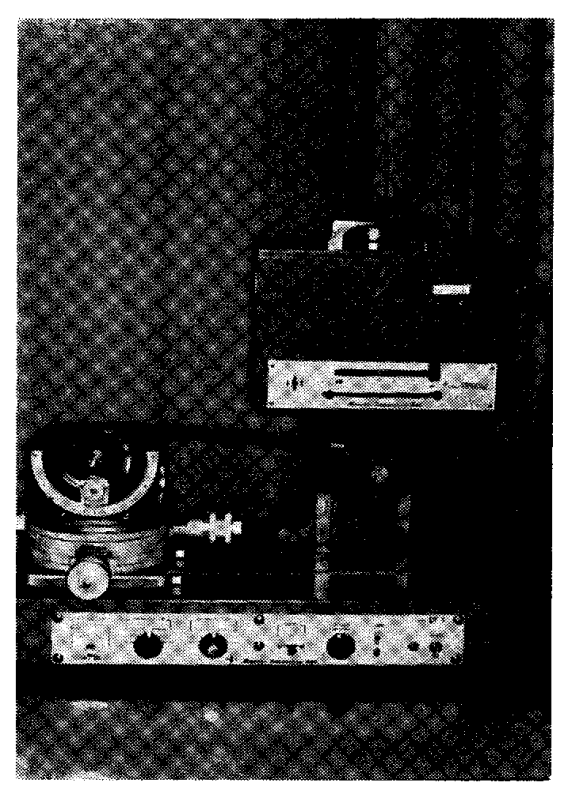

Fig.3 Formcorder.

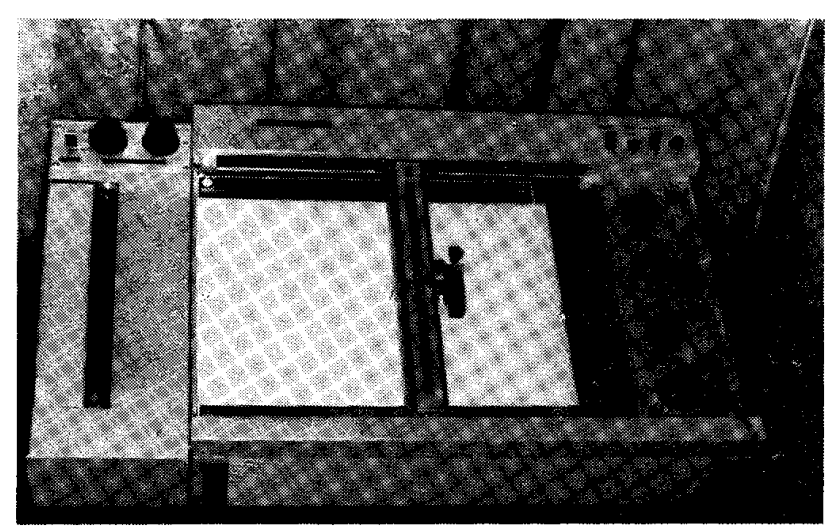

Fig.4 X-Y Recorder.

上硕模型基底面とガラス板との距離は，不亭の硬化膨 張による浮き上がりを考慮して，約 $5 \mathrm{~mm}$ 以内になるよ らにあらかしめ調整しておいだ'。

上顎模型基底面を製作したのち，Fig． 5 に示すよう に，下顎模型を咬頭嵌合位においてスティッキーワック スとマッチ棒とで固定し，著者の考案したガラス製平行 模型作製器により，下影模型基底面を沃定した。平行模 型作製器の平行度は $0.03 \mathrm{~mm} / 100 \mathrm{~mm}$ であった。 


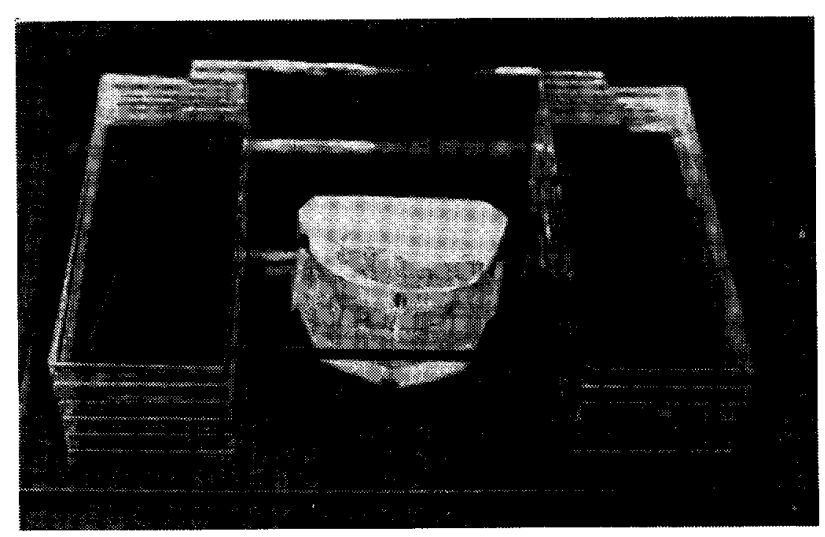

Fig. 5 Making base of lower model.

\section{C 测 定 方 法}

1 咬頭斜面の補綴学的平面に対する投身面積 a 咬合面の区分 (Fig. 6，7)

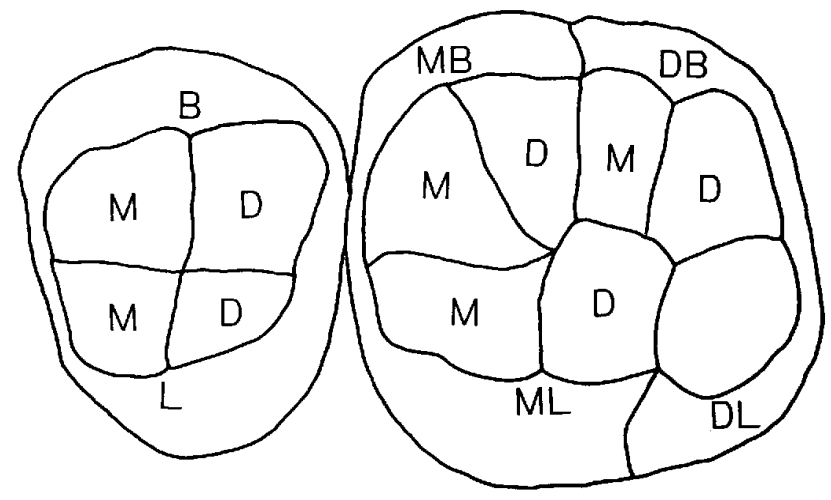

Fig.6 Classification of occlusal surface (upper).

M : Mesial inclined plane.

D : Distal inclined plane.

B : Buccal cusp.

MB : Mesiobuccal cusp.

DB : Distobuccal cusp.

L : Lingual cusp.

ML : Mesiolingual cusp.

DL : Distolingual cusp.

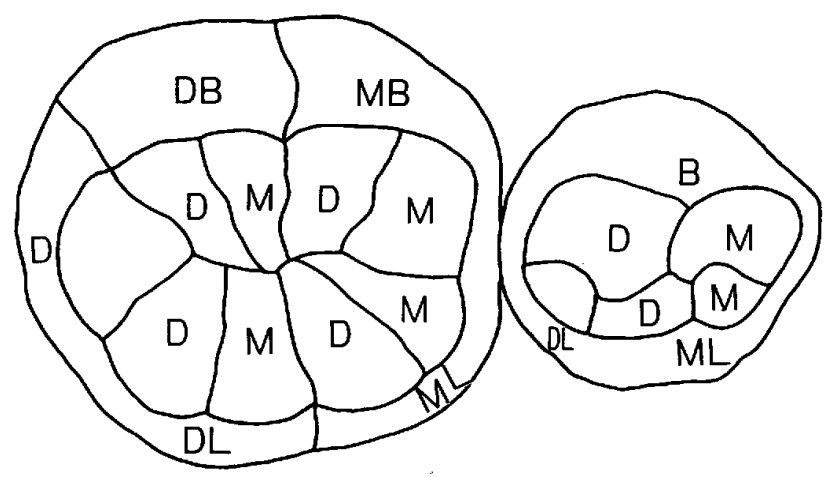

Fig.7 Classification of occlusal surface (lower).

D : Distal cusp.
模型上に, 咬合縁, 三角隆線, 咬頭頂, 中央溝, 煩側 溝, 舌側溝，近心小窞，抽よ゙遠心小營を，0.3mm， $3 \mathrm{H}$ 鉛筆で明示し，またクラスプサベャー（Ney社） により，模型基底面に対しての䒩冠最大畺隆部を描記し たのち, Nikon 万能投影器 (日本光学社, $6 \mathrm{C} \mathrm{T}-2$ 型) 在使用して, 拉大率10倍で半透明方眼紙（コクヨ， J I S-A 3， $1 \mathrm{~mm}, 250 \times 380$ ) 上にトレースした. トレースは暗室中で行なった。

つぎに，トレース紙上にて咬合面を区分し，咬合緣に より用まれる三角隆線の近心側を近心斜面, 遠心側を遠 心斜面とした，辺緣隆線の部分, 介在結節の部分, 付加 結節の部分は，隆起の程度によって峧頭斜面の役割りを はたすが7，本斫究においてはそれらは考慮しなかっ た.

三角隆線が不明瞭な咬頭や過剰咬頭，すなわち 6 ， $7, \overline{4}, \overline{5}$ の遠心舌側咬頭， $\overline{6}, \overline{7}$ の遠心咬頭，第 6 咬 頭，第 7 咬頭は，近心斜面と遠心斜面とに区分しなかっ た.

\section{b 测定方法}

トレース紙上に描記された，近心斜面と䞦心斜面とに 含まれる $1 \mathrm{~mm}^{2}$ 方眼の数により，面積を測定した。辺 緣部は方眼内の一部分を留める不定形を示すので, 著者 はまず，その斜面に完全に含まれる $1 \mathrm{~mm}^{2}$ 方眼の数 $x$ を数え，乙れに $1 \mathrm{~mm}^{2}$ 未満の方眼の数 $\boldsymbol{y}$ の $1 / 2$ を加え て，乙の合計を 100 で制り $(x+y / 2) \times 1 / 100$, 小数 点以下第 3 位を四读五入して面積を求めた。

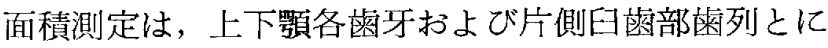
打ける，近心斜面と遠心斜面とを刘象として行なった。 また，菌牙の峧合縁で囲まれる部分を全盿合面とし，そ の投射面積をも求めた。

\section{c 測定誤差の検定 (Table 1)}

万能投影器による拡大描記誤差および方眼紙上での読 み取り詋差について，予備実験を行なった。すなわち， 半径 $5 \mathrm{~mm}$ の円と 1 辺 $10 \mathrm{~mm}$ 正方形とを，10倍执大で 10回トレースし，その投射面積を測定した。その結果， $(+0.28 \%) \sim(-0.35 \%)$ の誤差を伴うことがわかっ t:

II. 三角隆線の補緅学的平面に対する傾斜角度および 咬頭展開角度

\section{a 測定方法 (Fig. 8，9)}

形状測定器 (Fig. 3) とX-Yレコーダー (Fig. 4) とを使用し，臼蒾部各咬頭の三角隆線について，咬 頭頂より窩あるいは溝までを，X，Y方向の拡大率10倍 
Table 1 Error in Measuring Projective Area

$\left(\mathrm{mm}^{2}\right)$

\begin{tabular}{l|cccccccccc|cccc}
\hline \hline & 1 & 2 & 3 & 4 & 5 & 6 & 7 & 8 & 9 & 10 & $\bar{X}$ & $S^{2} x$ & Theo. & $\begin{array}{c}\text { Error } \\
(\%)\end{array}$ \\
\hline Circle & 78.94 & 78.69 & 78.77 & 78.65 & 78.80 & 78.67 & 78.57 & 78.62 & 78.83 & 78.69 & 78.72 & 0.0123 & 78.50 & +0.28 \\
Square & 99.54 & 99.44 & 99.72 & 99.51 & 99.77 & 99.71 & 99.67 & 99.92 & 99.66 & 99.52 & 99.65 & 0.0210 & 100.00 & -0.35 \\
\hline
\end{tabular}

Circle : Radius of $5 \mathrm{~mm}$.

$\overline{\mathrm{X}}:$ Mean

Square: Side of $10 \mathrm{~mm}$.

$S^{2} x:$ Variance.

Theo. : Theoretical value.

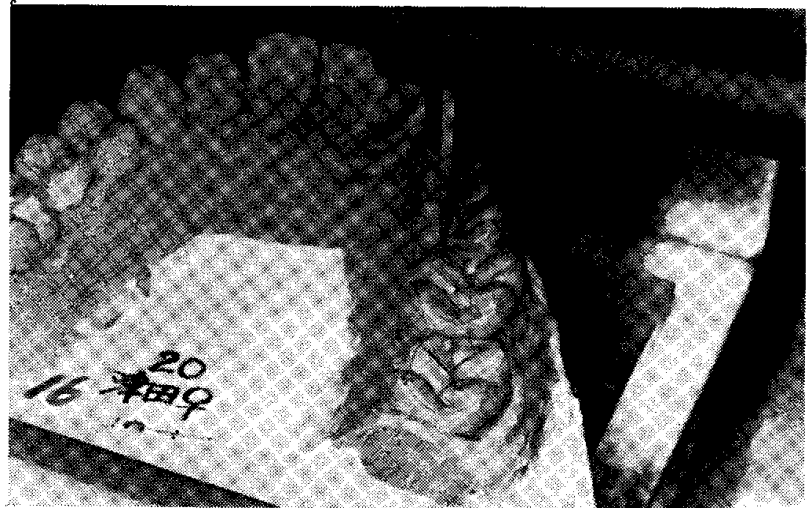

Fig.8 Recording triangular ridge.

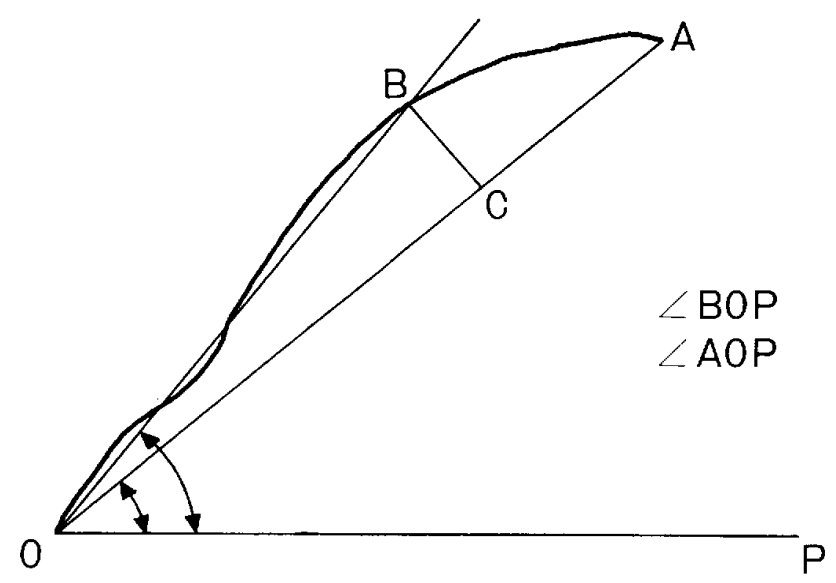

Fig.9 Triangular ridge inclination.

A-B-O : Triangular ridge .

$\mathrm{AO}\rfloor \mathrm{BC}$.

OP : Prosthetic plane.

で，方眼紙(コクョ，J I S-A 4 , $1 \mathrm{~mm}, 250 \times 180$ )

上に記録した。

三角隆線は，三次元的に複雑な曲線をなしているの で，一定の傾斜角度を考えることは無理であるが，著者 はつぎのようにして予備実験を行ない，その測定方法を 決定した，すなわち，咬頭頂を A, 窩（溝）をO, 直線
AOに対して三角隆線上より垂線を下し，その距離 B C が最大となる点を B, 補綴学的平面を O P とした場合 の， $\angle \mathrm{AOP}$ と $\angle \mathrm{BOP}$ と测定し，乙の 2 つの測定値 と矢崎 $\left.(1929)^{8}\right)^{\text {) }}$ の测定值と比較した (Table 2).

Table 2 は, 上顎煩側咬頭における傾斜角度を示すが, 他の咬頭においても，三者は同一の傾向を示したので， 測定方法が簡単な $\angle \mathrm{AOOP}$ 在三角隆線傾斜角度とした。

Table 2 Triangular Ridge Inclination $\left({ }^{\circ}\right)$

\begin{tabular}{c|c|cccccc}
\hline & $\mathrm{N}$ & $\underline{4} \mathrm{~B}$ & $\underline{5} \mathrm{~B}$ & $6 \mathrm{MB}$ & $\underline{6} \mathrm{DB}$ & $7 \mathrm{MB}$ & $\underline{7} \mathrm{DB}$ \\
\hline BOP & 6 & 49.5 & 46.1 & 29.9 & 24.9 & 31.5 & 18.9 \\
Yasaki & 50 & 45.68 & 38.52 & 29.93 & - & 23.03 & - \\
$\angle \mathrm{AOP}$ & 6 & 35.0 & 35.2 & 22.4 & 16.6 & 20.4 & 13.1 \\
\hline
\end{tabular}

Angle : Mean of right and left.

$\mathrm{N}$ : Sample size.

4 : Upper First Premolar.

5 : Upper Second Premolar.

$\underline{6}$ : Upper First Molar.

7 : Upper Second Molar.

B : Buccal triangular ridge.

MB : Mesiobuccal triangular ridge.

DB : Distobuccal triangular ridge.

なお， $\overline{4}, \overline{5}$ の煩側咬頭三角隆線が途中で二分してい る場合は，その中間を記録した，記録に先立って，北状 測定器の載物台表面（模型の基底面）を方腿紙の横目盛 に完全に一致させ, 方眼紙の横目盛が補経学的平面に平 行な平面を表わすようにした。

角度の測定には， $1 / 2$ 度まで目盛のついた 分度器（18 cm）を使用し，それ以下は目測によった。艾頭頂が窝

(溝)よりも下位にあり，角度が（一）を示した場合 は，平均值を算出する際それを除外した。

つぎに，頰側および 舌側咬頭の三角隆線傾斜角度よ り, 個々の咬頭展開角度を算出し, その平均值を求め 


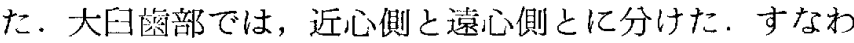
ち，6，7においては，近心煩側咬頭と近心舌側咬頭よ り近心側の角度を，遠心煩側咬頭と近心舌側咬頭より遠

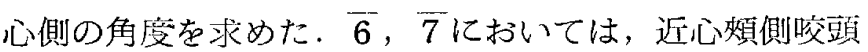
之近心舌側咬頭より近心側の角度を, 遠心煩側咬頭之遠 心舌側咬頭より遠心側の角度を求めた。

三角隆線が不明暸な咬頭，および低位にあり対合菡と 艾合しない咬頭，すなわち，6， 7 遠心舌側咬頭， 4 舌 側咬頭， $\overline{5}$ 遠心舌側咬頭，および $\overline{6} ， \overline{7}$ 還心咬頭は測定 しなかった。 b 測定誤美の検定（Table 3)

形状测定器とレコーダーの愦差を検定するため，10m $\mathrm{m}$ ゲージブロックを使用して予備実験を行なった。すな わち，1C倍括大で，10mmをX，Y方向にそれぞれ10回 記録し，それを精度 $1 / 20 \mathrm{~mm} の$ ギスで読み取った結 果, $\overline{\mathrm{X}}=10.00, \overline{\mathrm{Y}}=10.03$ となった。

この平均值より, 角度の愦差を求めると, $\tan \theta^{\prime}=10$. $03 / 10.00, \theta^{\prime}=45.09 . \tan \theta=10.00 / 10.00, \theta=45.00$. $\theta^{\prime}-\theta=0.09$ (度) となり, (+0.09度) の誤差であっ た.

Table 3 Error in Measuring Triangular Ridge Inclination

$(\mathrm{mm})$

\begin{tabular}{c|rrrrrrrrr|rrrr}
\hline & 1 & 2 & 3 & 4 & 5 & 6 & 7 & 8 & 9 & 10 & $\bar{X}, \bar{Y}$ & $S^{2} x, S^{2} Y$ & Theo. Error \\
$(\%)$
\end{tabular}
$\mathrm{X}, \overline{\mathrm{Y}}:$ Mean.
$\mathrm{S}^{2} \mathrm{x}, \mathrm{S}^{2} \mathrm{y}:$ Variance.

III 齿牙各咬頭頂の補綴学的平面に対する位置 a 测定方法 (Fig. 10)

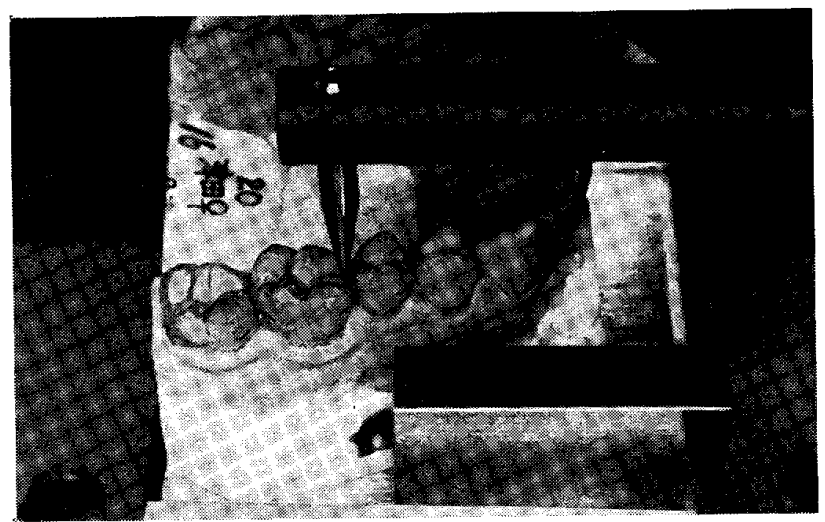

Fig.10 Recording cusp tips.

形状測定器とレコーダーとを使用し，中・側切苜の切 緣中央，犬菡尖頂，およびF壆部煩・舌侧咬頭頂を，㹡 大率 5 倍で方眼紙上に部録して, 崡列上の䨑牙各咬頭頂 と補緅学的平面との距離を求めた。

上䫟菡牙咬頭頂の記録に先立って, 形状測定器の載物 台上に25mmゲージブロックを置き，その上緣を方眼紙 の横目盛に一致させて記録したのち, 載物台上に上頢模 型を置き，咬頭頂を記録した。すなわち，基準となる補 綴学的平面（載物台表面）は，記録したゲージブロック 上縁よりも， $25 \mathrm{~mm} \times 5=125 \mathrm{~mm}$ 下方の横目盛となる.

上顎の記録を終えてから，上下顎模型を咬頭嵌合位で 固定して載物台上に置き，補経学的平面である上顎模型 基底面を方眼紙横目盛と一致させて記録したのち，上顎 模型をはずして，下顎咬頭頂を記録した。

距離の計測は，精度 $1 / 20 \mathrm{~mm}$ のノギスを使用して行な い，その值を1/5にして龹際の距離に補正した。

\section{b 澌定䛊差の検定（Table 4)}

$\mathrm{Y}$ 方向に扔ける形状測定器とレコーダーとの誤差，お よびノギスでの読み取り誤差について，予備実験を行な った。すなわち，10mmゲージブロックを使用して，Y 方向の拡大率 5 倍で10回記録し，てれを精度 $1 / 20 \mathrm{~mm} の$ ノギスで䛃みとった結果， $\bar{Y}=10.00, S^{2} x=0.0001$ と なった。

Table 4 Error in Measuring Distance

$(\mathrm{mm})$

\begin{tabular}{c|ccccccccc|cccc}
\hline & 1 & 2 & 3 & 4 & 5 & 6 & 7 & 8 & 9 & 10 & $\bar{Y}$ & $S^{2} \mathrm{Y}$ & Theo. Error \\
$(\%)$
\end{tabular}


IV 崡冠煩舌的最大幅径および咬頭頂間距離

a 測定方法 (Fig. 11，12)

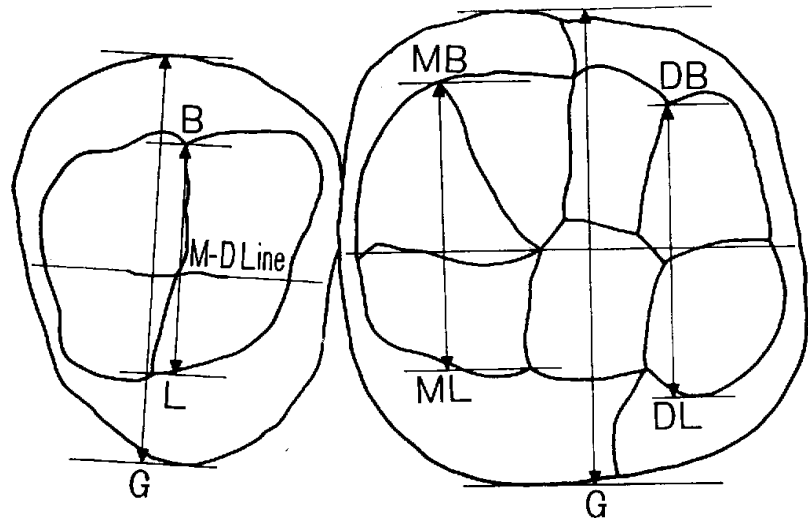

Fig.11 Greatest buccolingual tooth dimension and intercuspal distance (upper).

$\mathrm{G}$ : Greatest buccolingual tooth dimension. B-L, MB-ML, DB-DL : Intercuspal distance. M-D Line : Line which runs through mesial and distal pit.

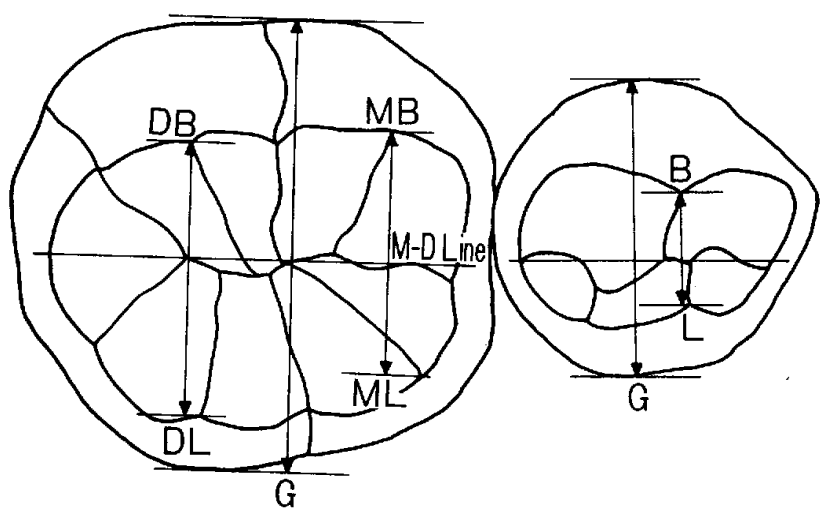

Fig.12 Greatest buccolingual tooth dimension and intercuspal distance (lower).
投射面積を測定する際に使用した咬合面図上におい て，各齒牙の近心小窩と遠心小窩とを結ぶ直線，すなわ ち，近遠心線に対して垂直な，齿冠煩舌的最大幅径抢よ び咬頭頂間距離を求めた。最大幅径は，近遠心線之平行 で, 煩側, 舌側縁の最突出部之接する煩側線, 舌側線を 描いた場合の，両線の最短距離とした。

大曰菌部においては，咬頭頂間距離を近心側と遠心側 とに分けて測定した， 7 が 3 咬頭の場合，遠心側の距離 は，遠心煩側咬頭頂と舌側咬頭頂間の距離を測定した。 $\overline{4}$ が大貌化している場合は, 媔側咬頭頂より三角隆線舌 側端までの距離を咬頭頂間距離とした。可遠心舌側峧頭 頂と $\overline{6}$ 遠心咬頭頂は考慮しなかった。

距離の計測は，精度 $1 / 20 \mathrm{~mm}$ のノ゙スを使用して行な い，実測值を $1 / 10$ にし，小数点以下第 3 位を阢捨五入し た。

b 測定誤差の検定 (Fig. 13, Table 5)

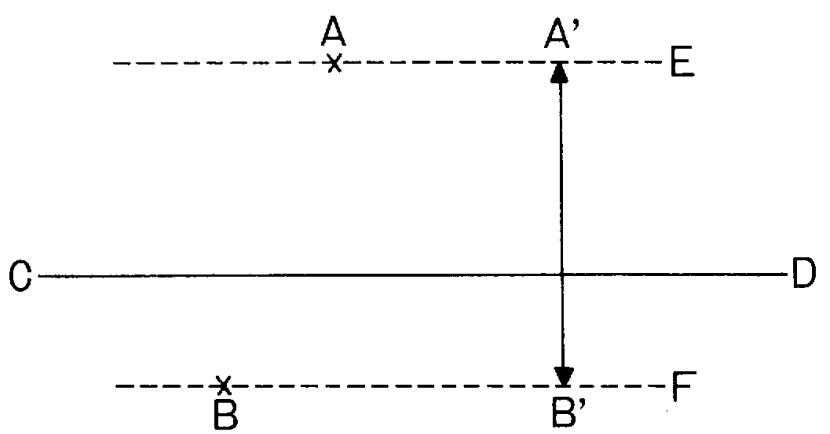

Fig.13 Error in measuring buccolingual distance.

$A^{\prime}-B^{\prime}$ : Buccolingual distance.

$\mathrm{CD}: \mathrm{M}-\mathrm{D}$ Line.

$\mathrm{AE} / / \mathrm{CD} / / \mathrm{BF}$.

Table 5 Error in Measuring Buccolingual Distance

$(\mathrm{mm})$

\begin{tabular}{|c|c|c|c|c|c|c|c|c|c|c|c|c|c|c|}
\hline & 1 & 2 & 3 & 4 & 5 & 6 & 7 & 8 & 9 & 10 & $\bar{X}$ & $S^{2} x$ & Theo. & $\overline{\text { Error }}(\%)$ \\
\hline$X$ & 9.99 & 10.01 & 10.01 & 9.99 & 10.01 & 10.02 & 10.01 & 10.01 & 10.01 & 9.99 & 10.01 & 0.0001 & 10.00 & $\div 0.1$ \\
\hline
\end{tabular}

万能投影器による拡大描記誤差，およびノギスによる 読み取り誤差について，つぎのような検定を行なった． 万能投影器の載物台上に， $10 \mathrm{~mm}$ ゲージブロックを置 き, その両辺を 10 倍で拡大投影し， 2 辺上の任意の 2 点 A，B 党トレース紙上に描記し，2 点A B間に，ゲージ ブロックの両辺と平行に直線 CDを描記した。直線 CD は近遠心線を表わす，つぎに，トレース紙上で，点A， $\mathrm{B}$ を通り, 直線 $\mathrm{CD}$ 亿平行な直線 $\mathrm{AE}, \mathrm{BF}$ を描き，乙
の 2 直線の最短距離 $\mathrm{A}^{\prime}-\mathrm{B}^{\prime}$ をノギスで測定し，实際の

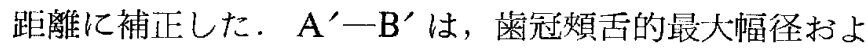
び咬頭頂間距離を表わす。この結果， $(+0.1 \%)$ の誤 差が存在することがわかった。

\section{$\mathrm{V}$ 統計的取り扱( 99}

a 推計学的処理法を用いて, 実測值より平均値, 不偏分散を求めた， $\mathrm{X}$ : 変量, $\mathrm{N}$ : 例数, $\overline{\mathrm{X}}$ : 平均值 
$\frac{\sum X}{N}, S^{2} x$ : 不偏分散 $\frac{\sum X^{2}-N \cdot \bar{X}^{2}}{N-1}$

b 二つの平均值の比較

まず，而標本の母集団の母分散が等しいか否かをみる ため, $S^{2} x, S^{2} y$ 分散比の検定を行なった。

1) $\mathrm{F}_{0}=\frac{\mathrm{S}^{2} \mathrm{x}}{\mathrm{S}^{2} \mathrm{Y}}\left(\mathrm{S}^{2} \mathrm{x}>\mathrm{S}^{2} \mathrm{Y}\right)$ 在求め, $\mathrm{F}_{0}<\mathrm{F}_{\mathrm{n}_{2}}^{\mathrm{n}_{1}} \alpha$ $=0.05$ の場合, 寸なわち, $\mathrm{F}_{0}$ 值が $\mathrm{F}$ 分布表の $\mathrm{n}_{1}=\mathrm{S}^{2} \mathrm{x}$ の $\mathrm{N}_{1}-1, \mathrm{n}_{2}=\mathrm{S}^{2} \mathrm{Y}$ の $\mathrm{N}_{2}-1, \alpha=0.05$ に相当する $\mathrm{F}$ 值 より小なる場合は，両 $\mathrm{X}, \mathrm{Y}$ は同一母集団に属している ので, 二つの平均值の差の統計的有意義性について， $\mathrm{t}$ 一検定を行なった。

$$
\begin{gathered}
\mathrm{t}_{0}=\frac{\mathrm{d}}{\mathrm{S}_{\mathrm{d}}}=\frac{\overline{\mathrm{X}}-\overline{\mathrm{Y}}}{\omega} \sqrt{\frac{\mathrm{N}_{1} \cdot \mathrm{N}_{2}}{\mathrm{~N}_{1}+\mathrm{N}_{2}}}, \\
\mathrm{~d}: \text { : } \text { :の平均值の差 } \mathrm{X}-\overline{\mathrm{Y}},
\end{gathered}
$$

$\mathrm{S}_{\mathrm{d}}: \mathrm{d}$ の標準偏差 $\sqrt{\frac{\omega^{2}}{\mathrm{~N}_{1}}+\frac{\omega^{2}}{\mathrm{~N}_{2}}}$,

$\omega^{2}: \mathrm{X}, \mathrm{Y}$ 共同分散

$$
\frac{\left(N_{1}-1\right) \cdot S^{2} x+\left(N_{2}-1\right) \cdot S^{2} y}{N_{1}+N_{2}-2} .
$$

$\left|\mathrm{t}_{0}\right| \geqq \mathrm{t} \begin{aligned} & \mathrm{n}=\mathrm{N}_{1}+\mathrm{N}_{2}-2 \\ & \alpha=0.05\end{aligned}$ の場合，すなわち，| $\mathrm{t}_{0} \mid$ が $\mathrm{t}$ 分布表 $の \mathrm{n}=\mathrm{N}_{1}+\mathrm{N}_{2}-2, \alpha=0.05$ 亿相当する $\mathrm{t}$ 值 より大なる場合，一つの平均值の差は，危険率 $5 \%$ 以下 において有意であるとした。

2) $\mathrm{F}_{0} \geq \mathrm{F}_{\mathrm{n}_{2}}^{\mathrm{n}_{1}} \alpha=0.05$ の場合には, 幽 $\mathrm{X}, \mathrm{Y}$ は同一母集団に属していないので，乙の場合は，Cochran一Cox の近似法による便法を用いた。

$$
\begin{gathered}
\mathrm{t}_{0}=\frac{\mathrm{d}}{\mathrm{S}_{\mathrm{d}}}=\frac{\overline{\mathrm{X}}-\overline{\mathrm{Y}}}{\sqrt{\mathrm{S}^{2} \overline{\mathrm{x}}+\mathrm{S}^{2} \overline{\mathrm{Y}}}}, \\
\mathrm{S}^{2} \overline{\mathrm{x}}: \overline{\mathrm{X}} \text { の分散 } \frac{\mathrm{S}^{2} \mathrm{x}}{\mathrm{N}_{1}}, \\
\mathrm{~S}^{2} \overline{\mathrm{y}}: \overline{\mathrm{Y}} \text { の分散 } \frac{\mathrm{S}^{2} \mathrm{v}}{\mathrm{N}_{2}} .
\end{gathered}
$$

つぎに, $\mathrm{t}$ 表から $\mathrm{n}_{1}=\mathrm{N}_{1}-1, \mathrm{n}_{2}=\mathrm{N}_{2} \cdots 1, \alpha=$ 0.05 に相当する $t_{1}, t_{2}$ を求め, Cochran-Cox の近似 法により, $\mathrm{t} c=\frac{\mathrm{S}^{2} \overline{\mathrm{x}} \cdot \mathrm{t}_{1}+\mathrm{S}^{2} \overline{\mathrm{y}} \cdot \mathrm{t}_{2}}{\mathrm{~S}^{2} \mathrm{~d}}$ を求めた。 $\left|\mathrm{t}_{0}\right| \geq \mathrm{t} \mathrm{c}$ の時，差 $\mathrm{d}$ は，危険率 $5 \%$ 以下において有意であるとし た.

c 全体的に有意差をみる場合は，つぎのようにし た. 項目別の美の検定值 $\mathrm{t}_{0}$ の総和 $\Sigma \mathrm{t}_{0}$ を, 比較した項 目数Kで除し, 平均比MRを算出し,つぎに, 平均比の 整準偏差 $S_{M R}=\frac{1}{\sqrt{\mathrm{K}-1}}$ を算出した。
平均比MRが，0在中心として，SMR をもって正規 分布するものとみなせば， $-\frac{M R}{S_{M R}} \geq 1.960$ である場合， 全体的に危険率 $5 \%$ 以下で有意であるとした。

\section{D 測定結果}

I 咬頭斜面の補経学的平面に対する投射面積 左右差, 男女差, 崡牙別の大きさ, および各菌牙と日 崡部崡列とに扔ける近心斜面と遠心斜面との差について 検討した。なお，近心斜西，遠心斜面，扔よび全咬合面 の投射面積を，それぞれM，D，およびTで表わした。

a 左 右 差 (Table 6,7 )

上下䫟の全部位とも，危険率 $5 \%$ 以下において有意差 はみられなかったので, 以下，左側について検討した。

b 男 女 差 (Table 6, 7)

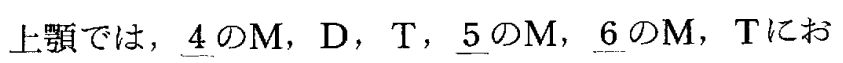
いて有意差がみられず，他の部位では有意差がみられ た.

下顎では, $\overline{4} 0 \mathrm{D}, \mathrm{T}, \overline{6} \omega \mathrm{D}, \mathrm{T}, \overline{7}$ のM, D, T に执て有意差がみられず，他の部位では有意差がみら れた。 MR/S は は上䫟 7.914，下顎 7.311となり上下顎 とも有意差がみられた。すなわち，上下顎とも男性が女 性よりも大きい值を示した。

上顎曰菌部崡列においては, $\mathrm{M} 6.77 \mathrm{~mm}^{2}, \mathrm{D} 7.66 \mathrm{~m}$ $\mathrm{m}^{2}, \mathrm{~T} 15.90 \mathrm{~mm}^{2}$, 下顎曰崡部曾列においては, $\mathrm{M} 6.2$ $0 \mathrm{~mm}^{2}, \mathrm{D} 6.53 \mathrm{~mm}^{2}, \mathrm{~T} 12.61 \mathrm{~mm}^{2}$ となり, 男女差は上 顎が下顎よりも著しかった。

c 畨牙别の大きさ (Table 6, 7)

1)_上顎

Tについて男性では $6 \quad\left(64.03 \mathrm{~mm}^{2}\right), 7 \quad(52.27 \mathrm{~m}$ $\left.\mathrm{m}^{2}\right), 4\left(32.12 \mathrm{~mm}^{2}\right), 5\left(30.86 \mathrm{~mm}^{2}\right)$, 女性で は $6 \quad\left(59.71 \mathrm{~mm}^{2}\right), 7 \quad\left(45.93 \mathrm{~mm}^{2}\right), \underline{4} \quad(29.81 \mathrm{~m}$ $\left.\mathrm{m}^{2}\right), 5\left(27.93 \mathrm{~mm}^{2}\right)$ であった。

Mについて舅性では $6 \quad\left(27.85 \mathrm{~mm}^{2}\right) ， 7 \quad 25.97 \mathrm{~m}$ $\left.\mathrm{m}^{2}\right), \underline{4}\left(14.56 \mathrm{~mm}^{2}\right), \underline{5}\left(14.52 \mathrm{~mm}^{2}\right)$, 女性で は $6 \quad\left(26.49 \mathrm{~mm}^{2}\right), \underline{7}\left(22.85 \mathrm{~mm}^{2}\right), \underline{5} \quad(13.4 .2 \mathrm{~m}$ $\left.\mathrm{m}^{2}\right), 4\left(13.38 \mathrm{~mm}^{2}\right)$ であった。

Dについて男性では $6 \quad\left(26.38 \mathrm{~mm}^{2}\right) ， 7 \quad(22.44 \mathrm{~m}$ $\left.\mathrm{m}^{2}\right), 4\left(17.56 \mathrm{~mm}^{2}\right), \underline{5}\left(16.34 \mathrm{~mm}^{2}\right)$, 女性で は 6 $\left(24.20 \mathrm{~mm}^{2}\right), 7 \quad\left(19.91 \mathrm{~mm}^{2}\right), 4 \quad(16.43 \mathrm{~m}$ $\left.\mathrm{m}^{2}\right), \underline{5}\left(14.52 \mathrm{~mm}^{2}\right)$ であった.

2) 下 影

Tについて男性では $\overline{6} \quad\left(59.29 \mathrm{~mm}^{2}\right), \overline{7}(48.42 \mathrm{~m}$ $\left.\mathrm{m}^{2}\right), \overline{5}\left(26.44 \mathrm{~mm}^{2}\right), \overline{4}\left(21.79 \mathrm{~mm}^{2}\right)$, 女性で 
Table 6 Projective Area of Inclined Plane (Upper)

$\left(\mathrm{mm}^{2}\right)$

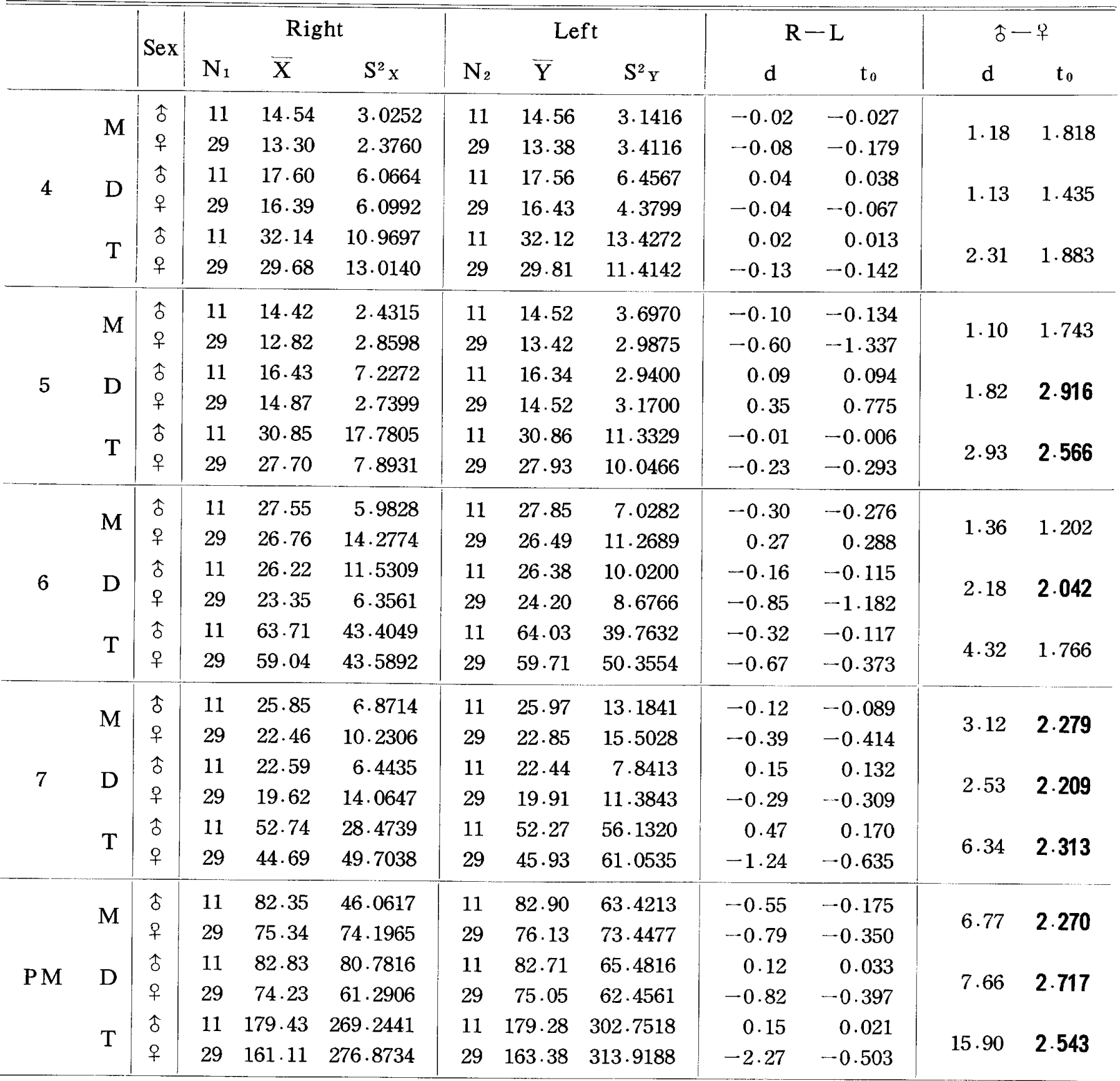

$\mathrm{MR} / \mathrm{S}_{\mathrm{MR}}(\hat{\delta}-$ o $)=\mathbf{7 . 9 1 4}$

PM : Arrangement of teerh.

$\mathrm{M}$ : Mesial inclined plane.

D : Distal inclined plane.

$\mathrm{T}$ : Total occlusal surface.

$\mathrm{R}-\mathrm{L}$ : Difference between right and left.

今-

$\mathrm{d}$ : Difference of mean.

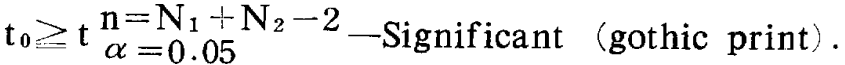

$\left(\mathrm{t}_{0}\right)=\frac{\overline{\mathrm{X}}-\overline{\mathrm{Y}}}{\sqrt{\mathrm{S}^{2} \overline{\mathrm{x}}+\mathrm{S}^{2} \overline{\mathrm{Y}}}} \geq \mathrm{tc}(\alpha=0.05)-$ Significant

(gothic print).

MR : Mean ratio.

$S_{M R}:$ Standard deviation of $M R$.

$\mathrm{MR} / \mathrm{S}_{\mathrm{MR}} \geqq 1.960(\alpha=0.05)$-Significant

(gothic print). 
Table 7 Projective Area of Inclined Plane (Lower)

$\left(\mathrm{mm}^{2}\right)$

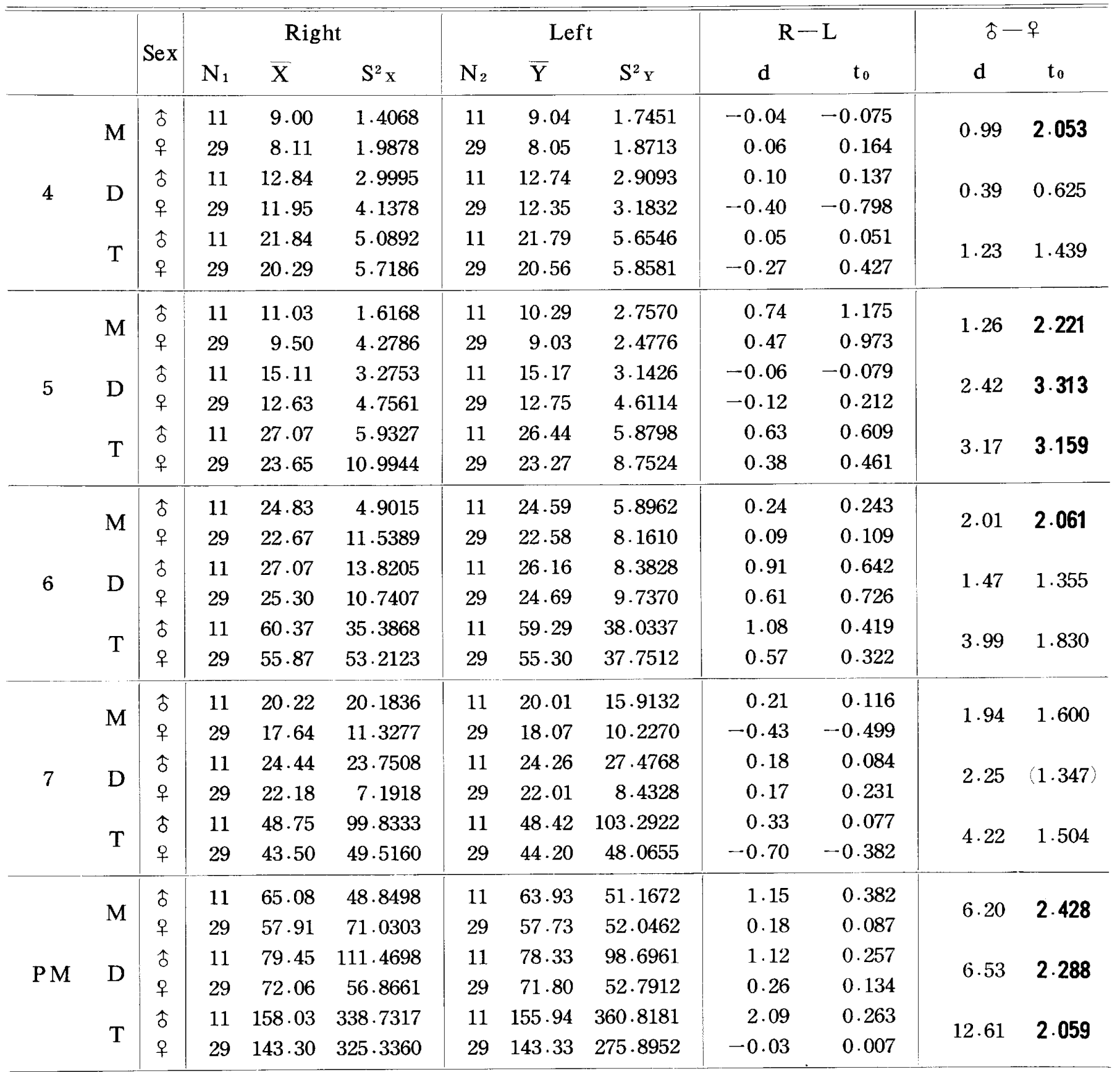

$\mathrm{MR} / \mathrm{S}_{\mathrm{MR}}($ 占- - + ) $=7.311$

は $\overline{6} \quad\left(55.30 \mathrm{~mm}^{2}\right\rangle, \overline{7} \quad\left(44.20 \mathrm{~mm}^{2}\right), \overline{5} \quad(23.27 \mathrm{~m}$ $\left.\mathrm{m}^{2}\right), \overline{4}\left(20.56 \mathrm{~mm}^{2}\right)$ であった.

Mについて男性では $6\left(24.59 \mathrm{~mm}^{2}\right) ， \overline{7}(20.01 \mathrm{~m}$ $\left.\mathrm{m}^{2}\right), \overline{5}\left(10.29 \mathrm{~mm}^{2}\right), \overline{4}\left(9.04 \mathrm{~mm}^{2}\right)$, 女性では $\overline{6}\left(22.58 \mathrm{~mm}^{2}\right), \overline{7}\left(18.07 \mathrm{~mm}^{2}\right), \overline{5}\left(9.03 \mathrm{~mm}^{2}\right)$,

$4\left(8.05 \mathrm{~mm}^{2}\right)$ であった。

Dについて男性では $\overline{6}\left(26.16 \mathrm{~mm}^{2}\right), \overline{7}(24.26 \mathrm{~m}$ $\left.\mathrm{m}^{2}\right), \overline{5}\left(15.17 \mathrm{~mm}^{2}\right), \overline{4}\left(12.74 \mathrm{~mm}^{2}\right)$, 女性で
は $\overline{6}\left(24.69 \mathrm{~mm}^{2}\right), \overline{7}\left(22.01 \mathrm{~mm}^{2}\right), \overline{5} \quad(12.75 \mathrm{~m}$ $\left.\mathrm{m}^{2}\right), \overline{4}\left(12.35 \mathrm{~mm}^{2}\right)$ であった.

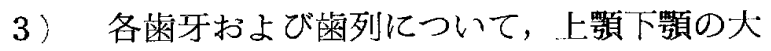
きさを比較すると， $6 \mathrm{D}$ 女性， $7 \mathrm{D}$ 男性および女性に

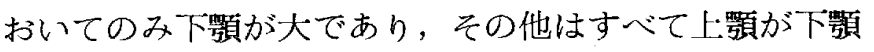
よりも大きい值を示した。

d 各歯牙と曰歯部歯列とにおける, 近心斜面と遠 心斜面との差（Table 8) 
Table $8 \quad M-D$

\begin{tabular}{|c|c|c|c|c|c|}
\hline & \multicolumn{2}{|c|}{$\hat{\jmath}$} & \multicolumn{2}{|c|}{ 우 } \\
\hline & & $\mathrm{d}$ & $\mathrm{t}_{0}$ & $\mathrm{~d}$ & $\mathrm{t}_{0}$ \\
\hline \multirow{5}{*}{ Upper } & 4 & -3.00 & -3.219 & -3.05 & -5.899 \\
\hline & 5 & -1.82 & -2.350 & -1.10 & -2.395 \\
\hline & 6 & 1.47 & 1.183 & 2.29 & 2.761 \\
\hline & 7 & 3.53 & 2.560 & 2.94 & 3.052 \\
\hline & PM & 0.19 & 0.056 & 1.08 & 0.499 \\
\hline \multicolumn{2}{|c|}{$M R / S_{M R}$} & & -0.708 & & -0.792 \\
\hline \multirow{5}{*}{ Lower } & 4 & -3.70 & -5.683 & -4.30 & -10.304 \\
\hline & 5 & -4.88 & -6.667 & -3.72 & -7.539 \\
\hline & 6 & -1.57 & -1.382 & -2.11 & -2.689 \\
\hline & 7 & -4.25 & -2.143 & -3.94 & -4.922 \\
\hline & PM & -14.40 & -3.908 & -14.07 & -7.404 \\
\hline \multicolumn{2}{|c|}{$\mathrm{MR} / \mathrm{S}_{\mathrm{MR}}$} & & -7.914 & & -13.144 \\
\hline
\end{tabular}

M-D : Difference between mesial and distal inclined plane in projective area.

1）男性

上類においては，龷， $\underline{5} ， \underline{7}$ で有意差がみられた。す なわち 4,5 ではDの方が大であり， 7 ではMの方が大 であった．歯列では有意差はみられなかった。

下顎においては， $\overline{4}, \overline{5}, \overline{7}$ ，歯列で有意差が みら れ，すべてDの方が大で，霜列での差は $14.40 \mathrm{~mm}^{2}$ であ った.

2) 女 性

上顥においては， $\underline{4} ， \underline{5} ， \underline{6} ， \underline{7}$ で有意差がみられ た。すなわち $4 ， 5$ ではDの方が，6，7ではMの方が 大であった，㐘列では有意差はみられなかった。

下顎においては， $\overline{4}, \overline{5}, \overline{6}, \overline{7}$ ，䨑列とすべて有意 差がみられ，いずれも Dの方が大であり，菌列での差は $14.07 \mathrm{~mm}^{2}$ であった。

3）日菊部菌列に扔ける $\mathrm{M} ， \mathrm{D} の \mathrm{~T} に$ 対する割 合 (Table 9)

Table 9 Ratio of $\mathrm{M}$ and $\mathrm{D}$ to $\mathrm{T}$

$(\%)$

\begin{tabular}{c|rc|cc}
\hline \multirow{2}{*}{$\mathrm{PM}$} & \multicolumn{2}{|c|}{$\mathrm{M}$} & \multicolumn{2}{c}{$\mathrm{D}$} \\
& f & 우 & 占 & 우 \\
\hline Upper & 46.2 & 46.6 & 46.1 & 45.9 \\
Lower & 41.0 & 40.3 & 50.2 & 50.1 \\
\hline
\end{tabular}

上顥ではM，Dとも約46\%であるのに対し，下顎では Mが約 $40 \% ， \mathrm{D} か ゙$ 約 $50 \%$ で，Dの方が約 $10 \%$ ぼ大きい 值を示した。

II 三角隆線の補緅学的平面に対する傾斜角度，およ び咬頭展開角度

三角隆線の傾斜角度は，煩側咬頭，舌側咬頭のそれを B， Lとし，近心煩側咬頭，遠心煩側咬頭のそれをM B , D B , 近心舌側咬頭, 遠心舌側咬頭のそれを $\mathrm{ML}$, D Lとした。

咬頭展開角度はOAで表わし，近心側，遠心側に分け た場合は，それぞれOAM，OADで表わした。

左右差, 男女差, 機能咬頭と非機能咬頭とにおける, 上下顎各咬頭の三角隆線傾斜角度の比較, および咬頭展 開角度について検討した。

a 左 右 差 (Table 10, 11)

上下顎の全部位とも，危険率 $5 \%$ 以下において有意差 はみられなかったので，以下，左側について検討した。

b 男 女 差 (Table 10, 11)

上頻では $5 \mathrm{~B}, 5 \mathrm{OA}$, 下蕷では $7 \mathrm{MB}, \overline{7} \mathrm{OAMK}$ おいて有意差がみられたが，他の部位ではみられなかっ

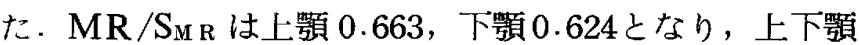
とも全体的に有意差はみられなかった。

c 機能咬頭と非機能咬頭とにおける，上下頧各咬 頭の三角隆線傾斜角度の比較（Table 12, Fig. 14, 15)

実際の上下顎咬頭接触関係とは異なるが2)，一応，上

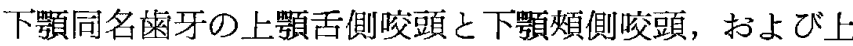
堮煩側咬頭と下頻舌側咬頭とにおける，三角隆線傾斜角 度を比較した。

1) 機能咬頭（上顎舌側咬頭と下顎煩側咬頭） 男性では， $7 \mathrm{ML}-\overline{7} \mathrm{MB}$ に扔いて有意差がみられた が，他の部位では有意差はみられなかった。しかし， MR/S R は2.255となり全体的には有意であった。

女性では， $4 \mathrm{~L}-\overline{4} \mathrm{~B}, 6 \mathrm{ML}-\overline{6} \mathrm{D} \mathrm{B}, 7 \mathrm{ML}-\overline{7}$ D Bに扔いて有意差がみられたが，他の部位ではみられ なかった， MR/S $/ \mathrm{SR}_{\mathrm{M}}$ は1.280で全体的には有意差はみら れなかった。

2 ）非機能咬頭(上顎煩側咬頭と下顎舌側咬頭) 男性では， $5 \mathrm{~B}-\overline{5} \mathrm{~L} ， 6 \mathrm{DB}-\overline{6} \mathrm{DL}$ において有意 差がみられたが，他の部位ではみられなかった。 MR/ $\mathrm{S}_{\mathrm{MR}}$ は0.728で全体的には有意差はみられなかった。

女性では， 7 D B- 7 D L に扔いて 有意差が みられ ず，他の部位では有意差がみられた．MR/S 
Table 10 Triangular Ridge Inclination and Open Angle (Upper)

$\left({ }^{\circ}\right)$

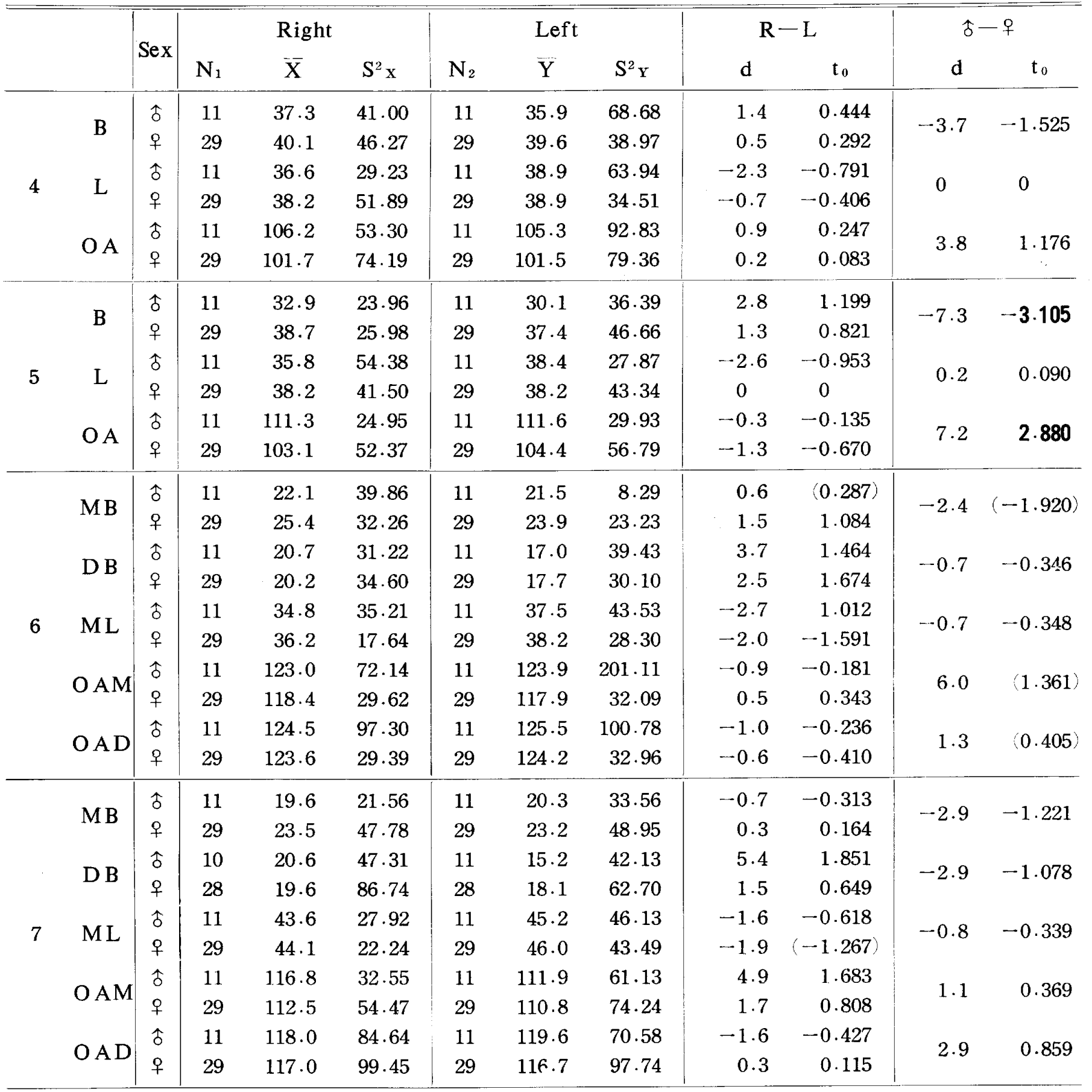

$\mathrm{MR} / \mathrm{S}_{\mathrm{MR}}(\hat{o}-q)=-0.663$

B : Buccal cusp.

L : Lingual cusp.

MB : Mesiobuccal cusp.

D B : Distobuccal cusp.

ML : Mesiolingual cusp.

D L : Distolingual cusp.
O A : Open angle.

O AM : Mesial open angle.

O AD : Distal open angle. 
Table 11 Triangular Ridge Inclination and Open Angle (Lower)

$\left({ }^{\circ}\right)$

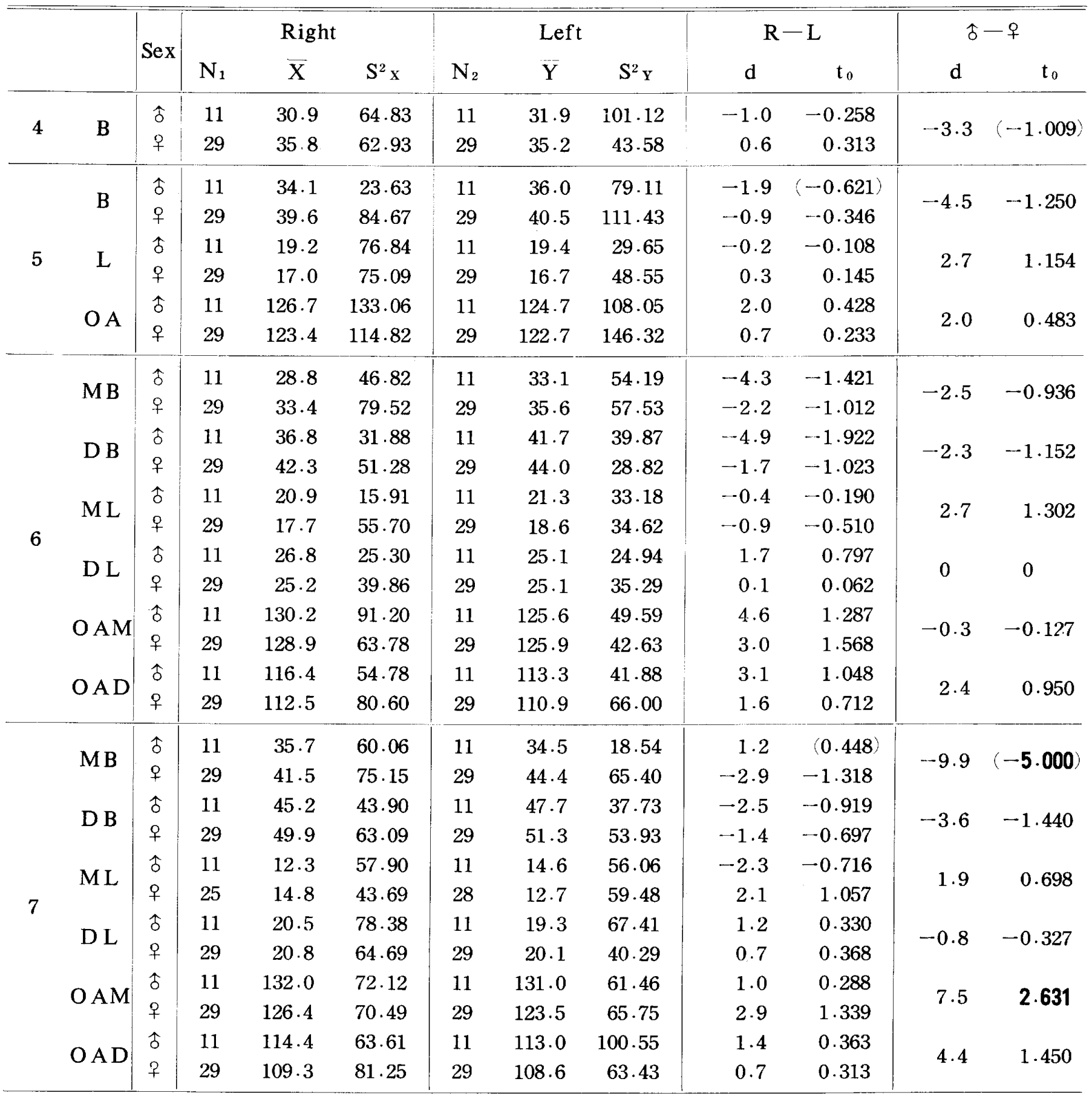

$\mathrm{MR} / \mathrm{S}_{\mathrm{MR}}(\hat{\delta}-o)=-0.624$ 
Table 12 Difference in Stamp Cusp, and That in Shearing Cusp ( $\left.{ }^{\circ}\right)$

\begin{tabular}{|c|c|c|c|c|c|}
\hline & \multicolumn{2}{|c|}{$\hat{o}$} & \multicolumn{2}{|c|}{ 우 } \\
\hline & & d & $\mathrm{t}_{0}$ & $\mathrm{~d}$ & $\mathrm{t}_{0}$ \\
\hline \multirow{7}{*}{ Stamp cusp } & $4 \mathrm{~L}-\overline{4} \mathrm{~B}$ & 7.0 & 1.812 & 3.7 & 2.256 \\
\hline & $5 \mathrm{~L}-\overline{5} \mathrm{~B}$ & 2.4 & 0.772 & --2.3 & $(-0.996)$ \\
\hline & $6 \mathrm{ML}-6 \mathrm{MB}$ & 4.4 & 1.479 & 2.6 & $(1.512)$ \\
\hline & $\overline{6} \mathrm{ML}-\overline{6} \mathrm{DB}$ & -4.2 & -1.528 & -5.8 & -4.138 \\
\hline & $7 \mathrm{ML}-7 \mathrm{MB}$ & 10.7 & 4.419 & 1.6 & 0.826 \\
\hline & $\underline{7} \mathrm{ML}-7 \mathrm{DB}$ & -2.5 & -0.907 & -5.3 & -2.893 \\
\hline & $\mathrm{MR} / \mathrm{S}_{\mathrm{MR}}$ & & 2.255 & & -1.280 \\
\hline \multirow{6}{*}{$\begin{array}{l}\text { Shearing } \\
\text { cusp }\end{array}$} & $5 \mathrm{~B}-\overline{5} \mathrm{~L}$ & 10.7 & 4.373 & 20.7 & 11.430 \\
\hline & $6 \mathrm{MB}-6 \mathrm{ML}$ & 0.2 & $(0.103)$ & 5.3 & 3.753 \\
\hline & $6 \mathrm{D} \mathrm{B}-6 \mathrm{DL}$ & -8.1 & -3.357 & -7.4 & -4.929 \\
\hline & $7 \mathrm{MB}-\overline{7} \mathrm{ML}$ & 5.7 & 2.002 & 10.5 & 5.378 \\
\hline & $7 \mathrm{DB}-7 \mathrm{DL}$ & -4.1 & -1.302 & -2.0 & -1.053 \\
\hline & $\mathrm{MR} / \mathrm{S}_{\mathrm{MR}}$ & & 0.728 & & 5.832 \\
\hline
\end{tabular}

$4,5,6,7:$ Upper tooth

$\overline{4}, \overline{5}, \overline{6}, \overline{7}$ : Lower tooth.

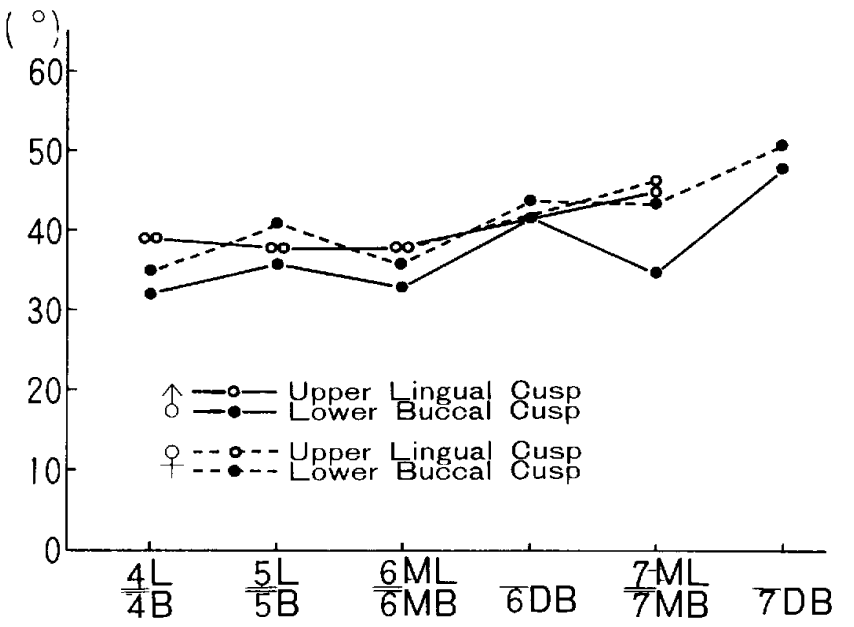

Fig.14 Triangular ridge inclination in stamp cusp.

で全体的に有意差がみられた。

上下顎の機能咬頭における角度差は, 男女合わせて平 均值で $4.4^{\circ}$, 非機能咬頭においては $7.5^{\circ}$ となり, 機能咬 頭の方が非機能咬頭よりも $3.1^{\circ}$ ほよ゙小であった。

Fig. 14，15に示すように，機能咬頭においては，男 女とも後方曰䨑部へ向かうにしたがって，しだいに角度 が大きくなり (約 $30 〜 50^{\circ}$ ), 非機能咬頭においては, 小曰歯部で約 $30 \sim 40^{\circ}$, 大曰霜部で約 $15 \sim 25^{\circ}$ であった。

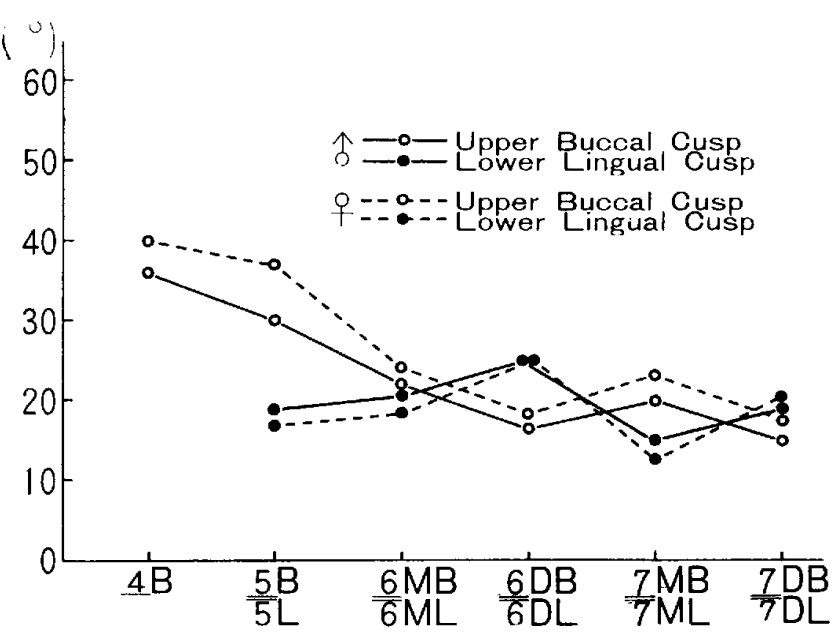

Fig.15 Triangular ridge inclination in shearing cusp.

d 愹頭展開角度 (Table 10, 11)

5 OA，6 OAM，7 OAMにおいて，下顎の方が上顎 よりも大であったが，6OAD，7 OADにおいては， 上顎の方が大であった。

e ま め

左側上下簤各歯牙における三角隆線傾斜角度，ならび に咬頭展開角度の男女の平均值をまとめて, Table 13 に示した。 
Table 13 Triangular Ridge Inclination and Open Angle

$\left({ }^{\circ}\right)$

\begin{tabular}{cc|cc|cc}
\hline & & \multicolumn{2}{|c|}{ Upper } & \multicolumn{2}{c}{ Lower } \\
& & Tri. & OA & Tri. & OA \\
\hline \multirow{4}{*}{4} & B & 37.8 & & 33.6 & - \\
& L & 38.9 & 103.4 & - & \\
\hline \multirow{2}{*}{5} & B & 33.8 & & 38.3 & 123.7 \\
& L & 38.3 & 108.0 & 18.1 & \\
\hline & M B & 22.7 & 120.9 & 34.4 & 125.8 \\
6 & D B & 17.4 & OAM & 42.9 & OAM \\
M L & 37.9 & 124.9 & 20.0 & 112.1 \\
& D L & - & OAD & 25.1 & OAD \\
\hline & M B & 21.8 & 111.4 & 39.5 & 127.3 \\
7 & D B & 16.7 & OAM & 49.5 & OAM \\
M L & 45.6 & 118.2 & 13.7 & 110.8 \\
D L & - & OAD & 19.7 & OAD \\
\hline
\end{tabular}

Tri. : Triangular ridge inclination.

\section{III 函牙各咬頭頂の補綴学的平面に対する位置}

左右差, 男女差, 抢よび 1， 的平面に平行な平面について検討した。

煩側咬頭頂を B , 舌側咬頭頂をLで表わし, 近心煩側 咬頭頂, 遠心煩側咬頭頂をそれぞれMB，D B, 近心舌 側咬頭頂, 遠心舌側咬頭頂をそれぞれML，DLで表わ した。また， 6 遠心咬頭頂はDで表わした。

\section{a 左 右 差 (Table 14, 15)}

全部位とも，危険率 $5 \%$ \%下において有意差はみられ なかったので, 以下, 左側について検討した。

b 男 女 差 (Table 14, 15)

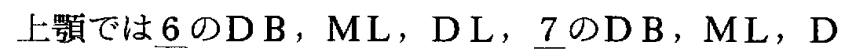
Lに扔いて有意差がみられ，MR/ $\mathrm{S}_{\mathrm{MR}}$ も5.805となり全 体的にも有意美がみられた。

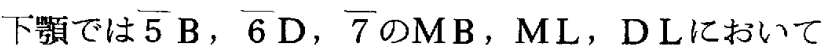
有意差がみられ，MR/ $\mathrm{S}_{\mathrm{MR}}$ も5.764となり全体的にも有 意差がみられた，すなわち，上下買とも男性が女性より も大であった：主として，目雨部で男女差がみられ，そ の差も目雨部へ向からにしたがって大となった。

c 1, 不通万補綴学的平面に平行な平面につ小 $\tau$ (Table 16, 17)

1，Iを通る補経学的平面に平行な平面を考えた場合 の，その平面に対する各咬頭頂の位置を示した。（一) はその平面より上方，（十）は下方にあることを示す．

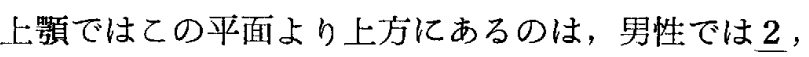

Table $16 \quad \underline{1}=0 \quad$ (Upper)

$(\mathrm{mm})$

\begin{tabular}{|c|c|c|c|c|c|}
\hline \multicolumn{3}{|c|}{ 古 } & \multicolumn{3}{|c|}{ 우 } \\
\hline 1 & \multicolumn{2}{|l|}{0} & 1 & \multicolumn{2}{|l|}{0} \\
\hline 2 & \multicolumn{2}{|l|}{-0.56} & 2 & \multicolumn{2}{|l|}{-0.48} \\
\hline 3 & \multicolumn{2}{|l|}{0.45} & 3 & \multicolumn{2}{|l|}{0.37} \\
\hline $4 \mathrm{~B}$ & $1.04 \mathrm{~L}$ & 0.51 & $4 \mathrm{~B}$ & $0.84 \quad \mathrm{~L}$ & 0.14 \\
\hline $5 \mathrm{~B}$ & $0.92 \mathrm{~L}$ & 1.02 & $5 \mathrm{~B}$ & $0.60 \mathrm{~L}$ & 0.28 \\
\hline $6 \mathrm{MB}$ & $0.39 \mathrm{ML}$ & 1.33 & $6 \mathrm{MB}$ & $-0.38 \mathrm{ML}$ & 0.35 \\
\hline D B & $0.51 \mathrm{DL}$ & 0.82 & D B & $-0.39 \mathrm{DL}$ & -0.30 \\
\hline $7 \mathrm{MB}$ & $-0.97 \mathrm{ML}$ & 0.28 & $7 \mathrm{MB}$ & $-2.00 \mathrm{ML}$ & -0.92 \\
\hline D B & $-1.66 \mathrm{D} \mathrm{L}$ & -1.24 & D B & $-2.87 \mathrm{DL}$ & -3.11 \\
\hline$(-)$ & \multirow{2}{*}{\multicolumn{5}{|c|}{$\begin{array}{l}\text { Cusp tip is upper than line which runs } \\
\text { through } 1 \text { and parallel with prosthetic } \\
\text { plane. } \\
\text { : Cusp tip is lower. }\end{array}$}} \\
\hline$(+)$ & & & & & \\
\hline
\end{tabular}

Table $17 \quad \overline{1}=0$ (Lower)

$(\mathrm{mm})$

\begin{tabular}{|c|c|c|c|c|c|}
\hline \multicolumn{3}{|c|}{$\hat{\delta}$} & \multicolumn{3}{|c|}{ 우 } \\
\hline 1 & 0 & & 1 & 0 & \\
\hline 2 & -0.13 & & 2 & -0.15 & \\
\hline 3 & -0.19 & & 3 & -0.13 & \\
\hline $4 \mathrm{~B}$ & $0.93 \quad \mathrm{~L}$ & 2.55 & $4 \mathrm{~B}$ & $0.32 \quad \mathrm{~L}$ & 2.06 \\
\hline \multirow[t]{2}{*}{$5 \mathrm{~B}$} & $1.67 \mathrm{ML}$ & 2.79 & $5 \mathrm{~B}$ & $0.76 \mathrm{ML}$ & 2.00 \\
\hline & D L & 2.59 & & D L & 2.28 \\
\hline $6 \mathrm{MB}$ & $2.01 \mathrm{ML}$ & 2.70 & $6 \mathrm{MB}$ & $0.99 \mathrm{ML}$ & 1.73 \\
\hline D B & 1.56 & & D B & 0.38 & \\
\hline D & $2.11 \mathrm{D} \mathrm{L}$ & 2.65 & $\mathrm{D}$ & $0.81 \mathrm{DL}$ & 1.44 \\
\hline $7 \mathrm{MB}$ & $1.03 \mathrm{ML}$ & 2.43 & $7 \mathrm{MB}$ & $-0.43 \mathrm{ML}$ & 1.18 \\
\hline $\mathrm{DB}$ & $0.08 \mathrm{DL}$ & 1.95 & D B & $-1.47 \mathrm{D} \mathrm{L}$ & 0.30 \\
\hline
\end{tabular}

(-) : Cusp tip is upper than line which runs through $\overline{1}$ and parallel with prosthetic plane.

$(-+)$ : Cusp tip is lower.

$7 の \mathrm{MB}, \mathrm{DB}, \mathrm{DL}$ ，女性では $2,6 の \mathrm{MB}, \mathrm{DB}$ ， D L ， 7 のすべての咬頭頂で, 他はその平面よりも下方 にあった。

下顎では上方にあるのは, 男性では $\overline{2}, \overline{3}$ ，女性では $\overline{2}, \overline{3}, \overline{7}$ の B , D Bで, 他はすべて下方にあった.

上下顎男女とも，7の部で急激に上方に傾斜してい た。 
Table 14 Distance from Cusp Tips to Prosthetic Plane (Upper)

( $\mathrm{mm})$

\begin{tabular}{|c|c|c|c|c|c|c|c|c|c|c|c|c|}
\hline & & \multirow{2}{*}{ Sex } & \multicolumn{3}{|c|}{ Right } & \multicolumn{3}{|c|}{ Left } & \multicolumn{2}{|c|}{$\mathrm{R}-\mathrm{L}$} & \multicolumn{2}{|c|}{ 今一早 } \\
\hline & & & $\mathrm{N}_{1}$ & $\bar{X}$ & $S^{2} x$ & $\mathrm{~N}_{2}$ & $\bar{Y}$ & $S^{2} Y$ & d & $t_{0}$ & $\mathrm{~d}$ & $\mathrm{t}_{0}$ \\
\hline \multirow{2}{*}{\multicolumn{2}{|c|}{1}} & $\hat{\delta}$ & 11 & 23.32 & 4.9449 & 11 & $23 \cdot 30$ & $4 \cdot 1123$ & 0.02 & 0.022 & \multirow{2}{*}{0.20} & \multirow{2}{*}{0.298} \\
\hline & & q & 29 & 23.09 & 3.4062 & 29 & $23 \cdot 10$ & 3.3729 & -0.01 & -0.021 & & \\
\hline \multirow{2}{*}{\multicolumn{2}{|c|}{2}} & $\hat{\delta}$ & 11 & 22.51 & 4.1699 & 11 & 22.74 & 2.4026 & -0.23 & -0.299 & \multirow{2}{*}{0.12} & \multirow{2}{*}{0.193} \\
\hline & & 우 & 29 & 22.63 & 2.5640 & 29 & 22.62 & 3.2869 & 0.01 & 0.022 & & \\
\hline \multirow{2}{*}{\multicolumn{2}{|c|}{3}} & $\hat{\jmath}$ & 11 & 23.74 & 4.0395 & 11 & 23.75 & 1.7577 & -0.01 & -0.014 & \multirow{2}{*}{0.28} & \multirow{2}{*}{0.494} \\
\hline & & 우 & 29 & 23.32 & 2.0992 & 29 & 23.47 & 2.8599 & -0.15 & -0.364 & & \\
\hline \multirow{4}{*}{4} & \multirow{2}{*}{ B } & $\uparrow$ & 11 & $24 \cdot 38$ & 3.7466 & 11 & 24.34 & 0.5502 & 0.04 & $(0.065)$ & \multirow{2}{*}{0.40} & \multirow{2}{*}{$(1.081)$} \\
\hline & & 우 & 29 & 23.64 & 2.0548 & 29 & 23.94 & 2.6944 & -0.30 & -0.742 & & \\
\hline & \multirow{2}{*}{$\mathrm{L}$} & 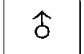 & 11 & 23.84 & 2.3232 & 11 & 23.81 & 1.1624 & 0.03 & 0.053 & \multirow{2}{*}{0.57} & \multirow{2}{*}{1.101} \\
\hline & & 우 & 29 & 23.11 & 1.6592 & 29 & $23 \cdot 24$ & 2.4664 & -0.13 & -0.344 & & \\
\hline \multirow{4}{*}{5} & \multirow{2}{*}{ B } & 占 & 11 & 24.41 & 2.9701 & 11 & 24.22 & 1.0358 & 0.19 & 0.314 & \multirow{2}{*}{0.52} & \multirow{2}{*}{ (1.106) } \\
\hline & & 오 & 29 & 23.46 & 2.4423 & 29 & 23.70 & 3.4955 & -0.24 & -0.532 & & \\
\hline & \multirow{2}{*}{$\mathrm{L}$} & $\delta$ & 11 & $24 \cdot 20$ & 2.4001 & 11 & 24.32 & 1.1211 & -0.12 & -0.212 & \multirow{2}{*}{0.94} & 1.744 \\
\hline & & 우 & 29 & 23.19 & 1.7115 & 29 & 23.38 & 2.7285 & -0.19 & -0.486 & & 1.744 \\
\hline & $\mathbf{M R}$ & $\uparrow$ & 11 & 23.74 & 2.8671 & 11 & 23.69 & 1.0450 & 0.05 & 0.084 & 0.97 & $(2.064)$ \\
\hline & & 우 & 29 & 22.60 & 2.9576 & 29 & 22.72 & 3.5925 & -0.12 & -0.253 & & \\
\hline & & $\hat{o}$ & 11 & 23.86 & 2.9254 & 11 & 23.81 & 1.0798 & 0.05 & 0.083 & 1.10 & $(2,292)$ \\
\hline 6 & & $q$ & 29 & 22.59 & 3.1566 & 29 & 22.71 & 4.0273 & -0.12 & -0.241 & 1.10 & $(Z \cdot Z \mathbf{Z Z})$ \\
\hline b & & 占 & 11 & $24 \cdot 51$ & 2.7306 & 11 & 24.63 & 1.2354 & -0.12 & -0.200 & 18 & (8) \\
\hline & & ㅇ & 29 & 23.23 & 2.4019 & 29 & 23.45 & 3.5196 & -0.22 & -0.487 & 1.10 & \\
\hline & $\mathrm{DI}$ & $\hat{o}$ & 11 & 23.97 & 2.2544 & 11 & 24.12 & 1.5057 & -0.15 & -0.257 & 1.32 & 2.034 \\
\hline & & 우 & 29 & 22.54 & 3.0239 & 29 & 22.80 & 3.9873 & -0.26 & -0.530 & 1.32 & 2.004 \\
\hline & $M B$ & $\hat{\delta}$ & 11 & $22 \cdot 40$ & 3.1972 & 11 & $22 \cdot 33$ & 2.1153 & 0.07 & 0.101 & 1.23 & 1.684 \\
\hline & IVI B & 우 & 29 & 20.96 & 3.4591 & 29 & $21 \cdot 10$ & 4.9959 & -0.14 & -0.259 & & \\
\hline & & $\hat{0}$ & 11 & 21.67 & 3.2559 & 11 & 21.64 & 2.0526 & 0.03 & 0.043 & 1.41 & $(2.274)$ \\
\hline 7 & D & q & 29 & 19.98 & 4.7300 & 29 & $20 \cdot 23$ & 5.9875 & -0.25 & -0.412 & 1.41 & 2.214 \\
\hline 7 & & $\hat{\delta}$ & 11 & 23.62 & $2 \cdot 2204$ & 11 & 23.58 & 1.6353 & 0.04 & 0.068 & 1.40 & 2.146 \\
\hline & ML & 우 & 29 & 21.92 & 3.0222 & 29 & $22 \cdot 18$ & 4.0014 & -0.26 & -0.530 & 1.40 & 2.140 \\
\hline & D L & 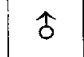 & 11 & 21.97 & 2.5735 & 9 & 22.06 & 2.8730 & -0.09 & -0.121 & 2.07 & 2.338 \\
\hline & UL & 우 & 21 & 20.04 & $4 \cdot 1372$ & 22 & 19.99 & 5.8422 & 0.05 & 0.073 & & \\
\hline
\end{tabular}

$\mathrm{MR} / \mathrm{S}_{\mathrm{MR}}($ 令- + ) $=\mathbf{5} . \mathbf{8 0 5}$ 
Table 15 Distance from Cusp Tips to Prosthetic Plane (Lower)

$(\mathrm{mm})$

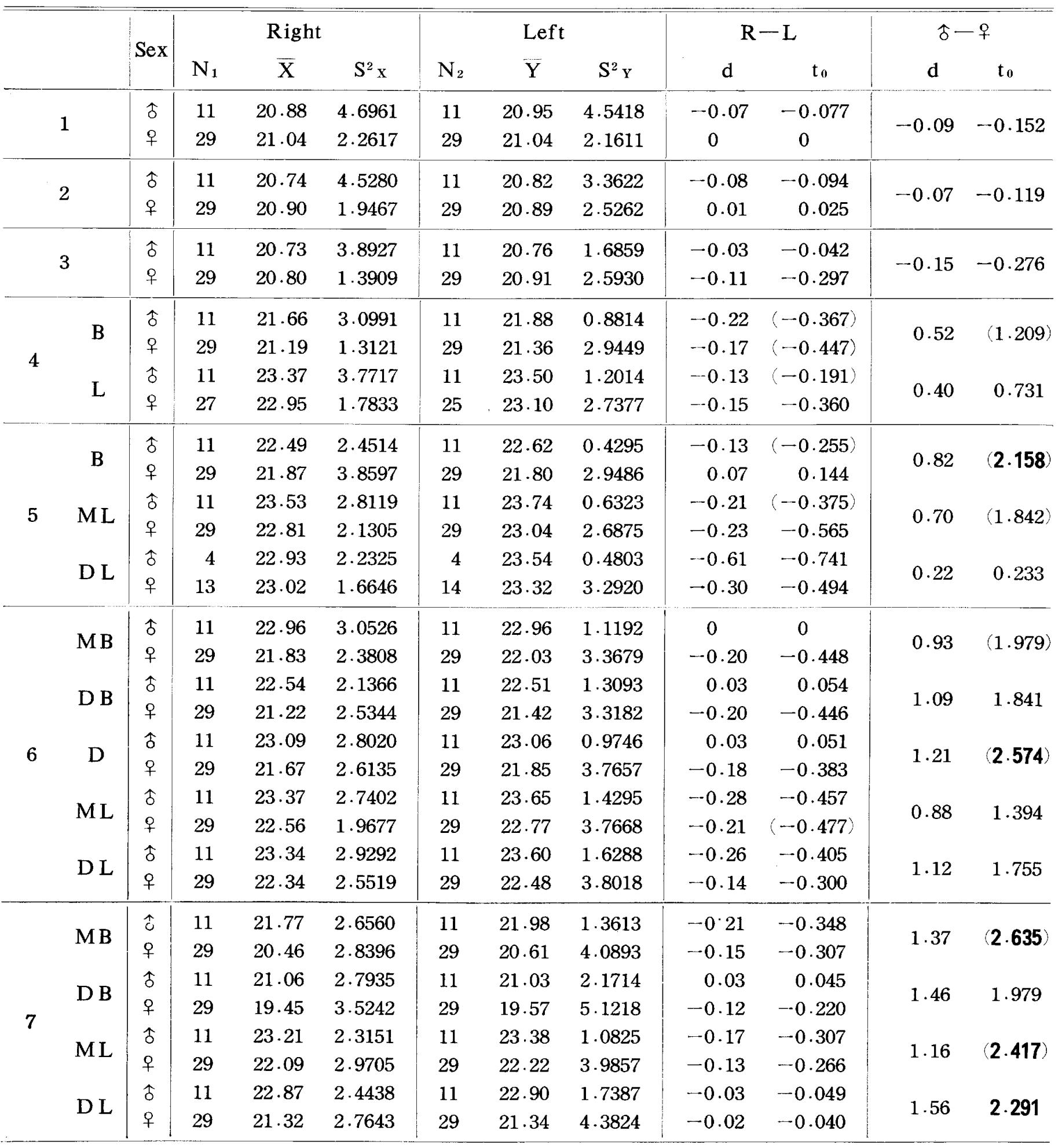

$\mathrm{MR} / \mathrm{S}_{\mathrm{MR}}(\hat{\delta}-q)=\mathbf{5} .764$ 
d Table 18に，7 D B 在基点として補緅学的平面 に平行な平面を考えた場合の，ての平面より下堮䨑牙各 咬頭頂までの距離を示した，男性では下と可 D B とを結 ぶ值線は，補緅学的平面に対しほとんど平行であり，女 性では前方傾斜を示した。

IV 歯冠煩舌的最大幅径および咬頭頂間距離

左右差，男女差，崡牙別の大きさ，および咬頭頂間距 離の最大幅径に対する割合について検討した，菌冠煩舌

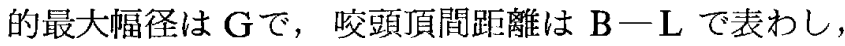
大曰菌部における近心側の咬頭頂閒距離を $\mathrm{MB}-\mathrm{ML}$ ， 遠心側のそれをD B-D Lで表わした。

a 左: 右 差 (Table 19, 20)

全部位とも危険率 $5 \%$ 以下において有意差はみられな かったので, 以下, 左側について検討した.

b 男 女 差 (Table 19, 20)

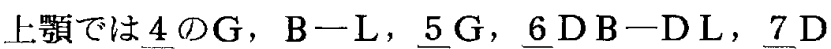
$\mathrm{B}$ 一DLに扑て有意差はみられず，下影では $\overline{4} \mathrm{~B}$ $\mathrm{L}, \overline{5} \mathrm{G}, \overline{6} の \mathrm{G}, \mathrm{DB}-\mathrm{DL}, \overline{7} の \mathrm{G}, \mathrm{DB}-\mathrm{DL}$ 亿
Table $18 \quad 7 \mathrm{DB}=0$ (Lower) $(\mathrm{mm})$

\begin{tabular}{|c|c|c|c|c|c|c|c|}
\hline \multicolumn{4}{|c|}{ 今 } & \multicolumn{4}{|c|}{ 우 } \\
\hline 1 & -0.08 & & & 1 & 1.47 & & \\
\hline 2 & -0.21 & & & 2 & 1.32 & & \\
\hline 3 & -0.27 & & & 3 & 1.34 & & \\
\hline $4 \mathrm{~B}$ & 0.85 & $\mathrm{~L}$ & 2.47 & $4 \mathrm{~B}$ & 1.79 & $\mathrm{~L}$ & 3.53 \\
\hline $5 \mathrm{~B}$ & 1.59 & ML & 2.71 & $5 \mathrm{~B}$ & 2.23 & ML & 3.47 \\
\hline & & D L & 2.51 & & & D L & 3.75 \\
\hline $6 \mathrm{MB}$ & 1.93 & ML & 2.62 & $6 \mathrm{MB}$ & 2.46 & ML & 3.20 \\
\hline D B & 1.48 & & & D B & 1.85 & & \\
\hline $\mathrm{D}$ & 2.03 & D L & 2.57 & $\mathrm{D}$ & 2.28 & D L & 2.91 \\
\hline $7 \mathrm{MB}$ & 0.95 & $M L$ & 2.35 & $7 \mathrm{MB}$ & 1.04 & $\mathrm{ML}$ & 2.65 \\
\hline D B & 0 & D L & 1.87 & D B & 0 & D L & 1.77 \\
\hline
\end{tabular}

$(-)$ : Cusp tip is upper than line which runs through $7 \mathrm{DB}$ and parallel with prosthetic plane.

$(+)$ : Cusp tip is lower,

Table 19 Greatest Buccolingual Tooth Dimension and Intercuspal Distance (Upper)

$(\mathrm{mm})$

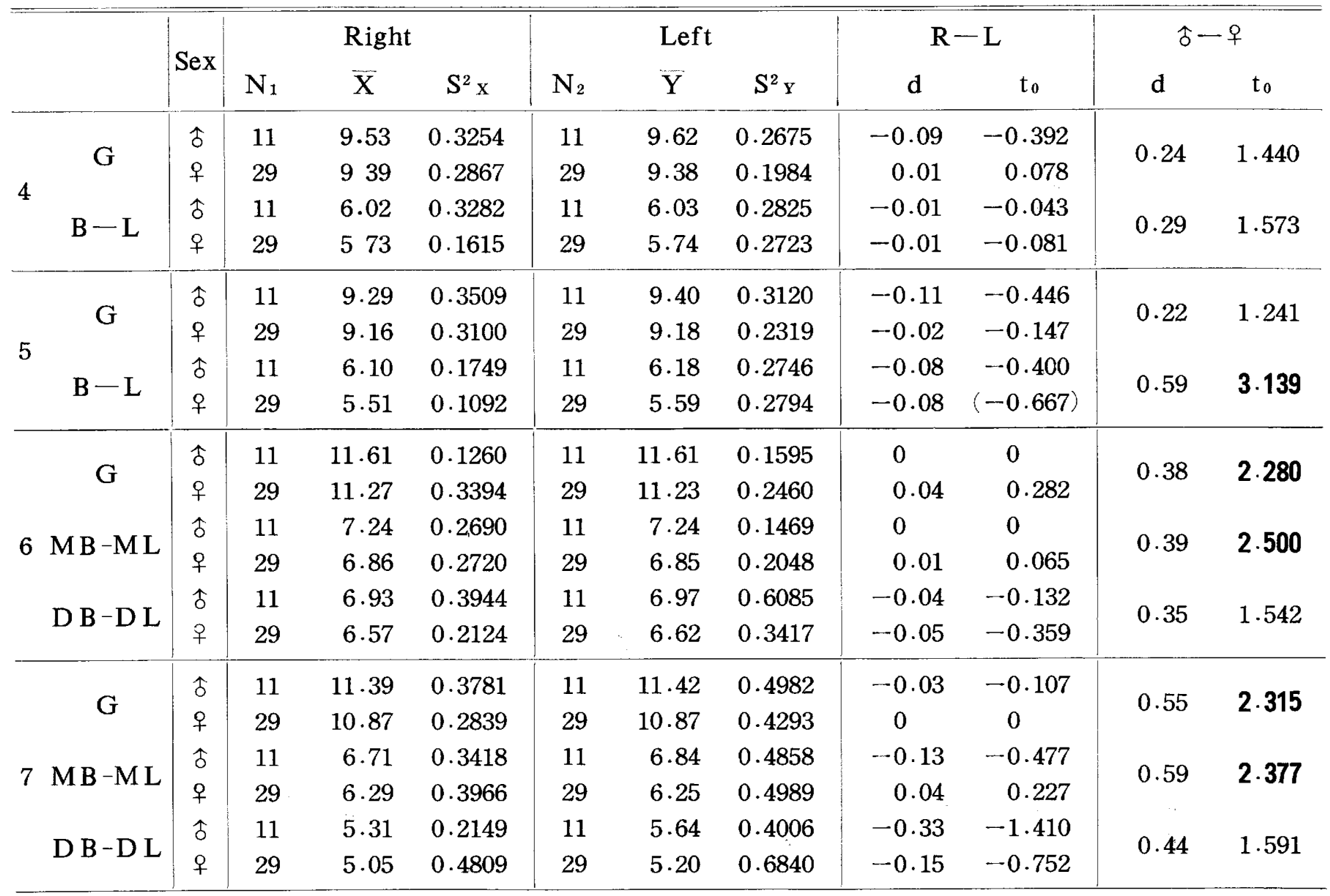

$\mathrm{MR} / \mathrm{S}_{\mathrm{MR}}(\hat{\delta}-$ o $)=6.006$ 
Table 20 Greatest Buccolingual Tooth Dimension and Intercuspal Distance (Lower)

$(\mathrm{mm})$

\begin{tabular}{|c|c|c|c|c|c|c|c|c|c|c|c|c|}
\hline & \multirow{2}{*}{$\operatorname{Sex}$} & \multicolumn{3}{|c|}{ Right } & \multicolumn{3}{|c|}{ Left } & \multicolumn{2}{|c|}{$R-L$} & \multicolumn{2}{|c|}{$1-q$} \\
\hline & & & $\mathrm{N}_{1}$ & $\bar{X}$ & $S^{2} x$ & $\mathrm{~N}_{2}$ & $\bar{Y}$ & $S^{2} Y$ & d & $t_{0}$ & d & $t_{0}$ \\
\hline \multirow{4}{*}{4} & & $\hat{o}$ & 11 & 7.97 & 0.1533 & 11 & 7.87 & 0.1135 & 0.10 & 0.635 & \multirow{2}{*}{0.35} & \multirow{2}{*}{2.243} \\
\hline & & q & 29 & 7.64 & 0.2357 & 29 & 7.52 & 0.2163 & 0.12 & 0.953 & & \\
\hline & \multirow{2}{*}{$B-L$} & 占 & 11 & 3.79 & 0.2229 & 11 & 3.67 & 0.1506 & 0.12 & 0.656 & \multirow{2}{*}{0.26} & \multirow{2}{*}{1.929} \\
\hline & & 우 & 29 & 3.40 & 0.1318 & 29 & 3.41 & 0.1375 & -0.01 & -0.103 & & \\
\hline \multirow{4}{*}{5} & \multirow{2}{*}{$G$} & 今 & 11 & 8.51 & 0.1176 & 11 & 8.51 & 0.0096 & 0 & (0) & \multirow{2}{*}{0.11} & \multirow{2}{*}{$(1.375)$} \\
\hline & & $q$ & 29 & 8.45 & 0.1297 & 29 & 8.40 & 0.1270 & 0.05 & 0.529 & & \\
\hline & \multirow{2}{*}{$B-L$} & $\hat{\jmath}$ & 11 & 4.49 & 0.2249 & 11 & 4.36 & 0.3599 & 0.13 & 0.566 & \multirow{2}{*}{0.44} & \multirow{2}{*}{2.177} \\
\hline & & ㅇ & 29 & 3.95 & 0.2679 & 29 & 3.92 & 0.3151 & 0.03 & 0.212 & & \\
\hline \multirow{6}{*}{6} & \multirow{2}{*}{ G } & $\hat{o}$ & 11 & 11.32 & 0.1372 & 11 & $11 \cdot 30$ & 0.0891 & 0.02 & 0.138 & \multirow{2}{*}{0.19} & \multirow{2}{*}{1.848} \\
\hline & & 우 & 29 & 11.11 & 0.1205 & 29 & 11.11 & 0.0840 & 0 & 0 & & \\
\hline & \multirow{2}{*}{ MB-ML } & 占 & 11 & 5.95 & 0.1942 & 11 & 5.84 & 0.1341 & 0.11 & 0.630 & \multirow{2}{*}{0.43} & \multirow{2}{*}{2.475} \\
\hline & & q & 29 & 5.43 & 0.3410 & 29 & 5.41 & 0.2759 & 0.02 & 0.136 & & \\
\hline & \multirow{2}{*}{ D B - D L } & 今 & 11 & 6.69 & 0.2607 & 11 & 6.59 & 0.2690 & 0.10 & 0.461 & \multirow{2}{*}{0.33} & \multirow{2}{*}{1.980} \\
\hline & & 우 & 29 & 6.36 & 0.3361 & 29 & 6.26 & 0.2008 & 0.10 & 0.733 & & \\
\hline \multirow{2}{*}{\multicolumn{2}{|c|}{ G }} & 今 & 11 & 10.81 & 0.3876 & 11 & 10.82 & 0.2519 & -0.01 & -0.041 & 0.23 & 1.158 \\
\hline & & 우 & 29 & 10.52 & 0.2798 & 29 & 10.59 & 0.3298 & -0.07 & -0.485 & 0.20 & \\
\hline 7 & MB-ML & $\hat{\delta}$ & 11 & $5 \cdot 18$ & 0.4132 & 11 & 5.23 & 0.4791 & -0.05 & -0.175 & 0.50 & 2136 \\
\hline & $10 \mathrm{D}$ & q & 29 & 4.66 & 0.4444 & 29 & 4.73 & 0.4196 & -0.07 & -0.404 & 0.00 & 2.130 \\
\hline & D B -D L & $\hat{\delta}$ & 11 & 5.87 & 0.6038 & 11 & 5.75 & 0.7735 & 0.12 & 0.340 & 0.16 & 0.610 \\
\hline & & 우 & 29 & 5.55 & 0.5815 & 29 & 5.59 & 0.4727 & -0.04 & -0.209 & 0.10 & 0.010 \\
\hline
\end{tabular}

$\mathrm{MR} / \mathrm{S}_{\mathrm{MR}}(\hat{\delta}-$ - + ) $=\mathbf{5 . 3 8 4}$

おいて有意差がみられなかった。しかし，上下蕷とも $\mathrm{MR} / \mathrm{S}_{\mathrm{MR}}$ は6.006，5.384で，いずれも全体的には有意 の差であった。すなわち，上下靧とも爾冠最大幅径およ び咬頭頂間距離において，罗性が女性より大であった。

c 蒾牙別の大きさ

1）雨冠最大幅径について

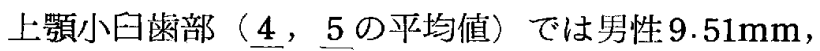
女性 $9.28 \mathrm{~mm}$, 大曰歯部 ( 6,7 の平均值) では男性 $11.52 \mathrm{~mm}$, 女性 $11.05 \mathrm{~mm}$ であった。

下類小曰崡部 ( $\overline{4}, \overline{5}$ の平均值) では男性 $8.19 \mathrm{~mm}$, 女性 $7.96 \mathrm{~mm}$, 大囦雨部 ( $\overline{6}, \overline{7}$ の平均值) では男性 $11.06 \mathrm{~mm}$, 女性 $10.85 \mathrm{~mm}$ であり, 小曰歯部, 大曰䨑部 とも上顎が下顎より大であった。

画牙別の大きさの順序は，上顎男性で 6 (11.61mm)， $\underline{7}(11.42 \mathrm{~mm}), \underline{4}(9.62 \mathrm{~mm}), 5(9.40 \mathrm{~mm})$, 女 性で6 (11.23mm), $7(10.87 \mathrm{~mm}), 4$ (9.38mm), 5 (9.18mm)，下買男性で $6(11.30 \mathrm{~mm}), \overline{7}$ (10. $82 \mathrm{~mm}), \overline{5}(8.51 \mathrm{~mm}), \overline{4}(7.87 \mathrm{~mm})$ ，女性で $\overline{6}$
$(11.11 \mathrm{~mm}), \overline{7}(10.59 \mathrm{~mm}), \overline{5}(8.40 \mathrm{~mm}), \overline{4}$ (7.52mm) であった.

2) 咬頭頂間距離について

上顎小曰歯部（4， 5 の平均值）では男性 $6.11 \mathrm{~mm}$ ， 女性 $5.67 \mathrm{~mm} ， 6$ (MとD よの平均值) では男性 $7.11 \mathrm{~m}$ $\mathrm{m}$, 女性 $6.74 \mathrm{~mm}, 7$ ( $\mathrm{M}$ と D との平均值) では男性 $6.24 \mathrm{~mm}$ ，女性5.73mmであった。

下顎小曰菡部 ( $\overline{4}, \overline{5}$ の平均值) では男性 $4.02 \mathrm{~mm}$, 女性 $3.67 \mathrm{~mm}, \overline{6}$ (MとD との平均值) では男性 $6.22 \mathrm{~m}$ $\mathrm{m}$, 女性 $5.84 \mathrm{~mm}, \overline{7}$ （Mと D との平均值）では男性 $5.49 \mathrm{~mm}$, 女性 $5.16 \mathrm{~mm}$ であり, 小田菌部, 大曰雨部と も上頻が下瀕より大であった。

崡牙別の大きさの順序は，上額男性で 6 ( $(7.11 \mathrm{~mm})$, $\underline{7}(6.24 \mathrm{~mm}), \underline{5}(6.18 \mathrm{~mm}), \underline{4}(6.03 \mathrm{~mm})$, 女 性で $6(6.74 \mathrm{~mm}), \underline{4}(5.74 \mathrm{~mm}), \underline{7}(5.73 \mathrm{~mm})$, $5(5.59 \mathrm{~mm})$ であり，下顎男性で $\overline{6}(6.22 \mathrm{~mm}), \overline{7}$ $(5.49 \mathrm{~mm}), \overline{5}(4.36 \mathrm{~mm}), \overline{4}(3.67 \mathrm{~mm})$ ，女性 で $\overline{6}(5.84 \mathrm{~mm}), \overline{7}(5.16 \mathrm{~mm}), \overline{5}(3.92 \mathrm{~mm})$, 
$\overline{4}(3.41 \mathrm{~mm})$ であった.

d 咬頭頂間距離の踩冠最大幅径に対する割合 (Table 21)

Table 21 Ratio of Intercuspal Distance to Greatest Buccolingual Tooth Dimension

$(\%)$

\begin{tabular}{|c|c|c|c|c|c|c|c|}
\hline \multirow{2}{*}{ Jaw } & \multirow{2}{*}{ Sex } & & & \multicolumn{2}{|c|}{6} & \multicolumn{2}{|c|}{7} \\
\hline & & & & M & $\mathrm{D}$ & $\mathbf{M}$ & $\mathrm{D}$ \\
\hline \multirow{2}{*}{ Upper } & $\hat{\delta}$ & 62.7 & 65.7 & 62.4 & 60.0 & 59.9 & 49.4 \\
\hline & 우 & 61.2 & 60.9 & 61.0 & 58.9 & 57.5 & 47.8 \\
\hline \multirow{2}{*}{ Low } & 古 & 46.6 & 51.2 & 51.7 & 58.3 & 48.3 & 53.1 \\
\hline & q & 45.3 & 46.7 & 48.7 & 56.3 & 44.7 & 52.8 \\
\hline
\end{tabular}

$\mathrm{M}: \mathrm{MB}-\mathrm{ML} . \quad \mathrm{D}: \mathrm{DB}-\mathrm{DL}$.

上額男性では約49〜66\%，女性では約 $48 〜 61 \%$ であ り，上顎大曰歯部においては，遠心が近心よりも小さい 值を示した。下顎男性では約47〜 58\%，女性では約45〜 $56 \%$ であり，下顎大臼霜部では，遠心が近心よりも大で あった。 また，男女とも $7 \mathrm{D}(\mathrm{DB}-\mathrm{DL}$ ）を除き，上 䫟の方が下顎よりも大であった。

\section{$\mathrm{E}$ 考 察}

I 咬頭斜面の補経学的平面に対する投射面積

a 各歯牙咬合面の投射面積について

咬頭斜面の大きさは，咬合面に加わる咬合圧（咀嚼圧 ）の方向，抢よび大きさを決定する重要な要素になると 思われる。

Wilson $(1920)^{101}{ }^{0}$, Silverman $(1962)^{11)}$ は, 咀嚼筋 の合力の方向は咬合平面に対して垂直であると述べてい るが，このことは，人工雬排列の基準となる咬合平面， すなわち, 補経学的平面の適正な再現を行なう上で極め て重要なとととなる12)。

投射面積は䨓牙咬頭傾斜角度，歯牙の近遠心的および 煩舌的傾斜，咬頭頂間距離等により強く影響され，実面 積とは異なってくるが，著者は補経学的平面に対する曰 䨑部天然雪の咬頭斜面の投射面積を測定し，その值と， 補綴学的平面に対し垂直に加わる咬合压の大きさとを比 較し考察を加えた。

上下簤とも左右差がみられなかったので，左側につい て男女差を検討したとてろ，上下頻とも男女差がみられ た。これは，歯牙の男女に扔ける大きさの相違によるも
のと思われる。

歯牙別の大きさの順序についてみると，上顴の全咬合 面，近心斜面，遠心斜面では，男女とも大体 $6 ， \underline{7}$, 4，5の順序であり，下顎では男女とも $\overline{6}, \overline{7}, \overline{5}, \overline{4}$ であった。

ここで, 各研究者の天然霜列上での咬合力の大きさの 順序と比較してみると，小西（1959）131 では $6 ， 7$ ， 4，5，紏川（1959）14)では10才代から50才代までを通 じ $6,7 ， 5 ， 4$ の順序となり，高見沢 $(1965)^{15}$ では

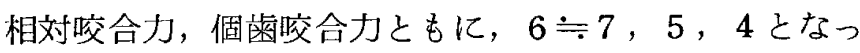
ている，各研究者における咬合力の測定値は，被検者の

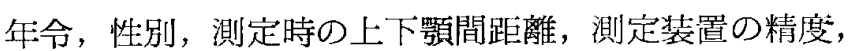
および感度等の条件により異なるが，その大きさは大曰 䨑部が小曰霜部よりも大で, ての点では各研究者ともす べて一致している，咀嘫圧について三浦ら $(1954)^{16}$ は，食品の性状により影響されること大であるが，最大 咬合圧の $1 / 2 \sim 1 / 4$ 程度であるとしている。また，溝上

(1966） ${ }^{17)}$ は，食品介在時に崡牙の担う力を咀嚼力とい い，食品無介在時の力を咬合力と表現するならば，実際 の咀嚼にあたっては，霖牙は咀㘉力と咬合力とを合わせ 担うととになると述へてている。吃に，咀嚼時において も，加わる力は大田歯部が心田崡部よりも大きいと考え られる。

矢崎 $(1929)^{181}$, 長谷川 $(1964)^{19)}$, 藤田 $(1972)^{201}$, Gosen $(1974)^{21}$ ) らは，下䋶における第級のテコの存 在を認め，咬合力は，その発現部位が筋の収縮力の作用 線江近いほど大きく，第正級槓杆作用によって発現する としている.

実際，各研究者の咬合力の測定值をみても，支点であ る顆頭に近い大曰菊部ほど大きい值を示し，顆頭から遠 い前歯部では小さい值を示している.

以上述べたととから，咬頭斜面の投射面積と咬合力と の大きさの関係についてみると，咬合力が大きい大雷 部ほど投射面積も大きくなり，咬合力が小さい小臼菌部 では投射面積も小さくなっている。

また，爾根表面積の大きさの順序は，Tylman (1970) 22)，羽賀ら $(1975)^{23}$ 亿よると，上顎で $6 ， \underline{7} ， \underline{4}$, 5 , 下頜で $\overline{6}, \overline{7}, \overline{5}, \overline{4}$ と報告されておう，乙の順序 は，投射面積の大きさの順序と一致した。

以上のように，大きい峧合圧珈わる歯牙ほど，その 投射面積と雬根表面積も大となり，すなわち，歯牙と崡 牙支持組織の単位面積あたりの咬合圧が減少することに なり，咀嚼機構における䨑牙の合目的性が示され，大田 歯部咬合面は食物を粉砕するのに好都合な形態をしてい 
ると考えられる。

また，鹿島（1966） ${ }^{24}$ は，咀噮により顔面頭㥺に生ず る応力を, 抵抗線丕計により測定し, 荬牙荷重が罒菌一 移動するにつれて, 顔面各部の応力は減少し, より均等 な応力分布を示すとし, 現代人頭蓋の曰蒾部に抢ける咀 嚼に対する合目的性を述べている。

b 近心斜面と遠心斜面の面積比較について

曰歯部爾列における近心斜面と遠心斜面との差をみる と, 上顎では男女とも有意差がみられなかったが，下顎 では男女とも有意差がみとめられ，いずれも遠心斜面が 近心斜面よりも大きい值を示した。，その差は男性で14.4 $0 \mathrm{~mm}^{2}$, 女性で $14.07 \mathrm{~mm}^{2}$ であった。乙れは, 上䫑では 4, 5 が近心䎲傾斜し， 6 ，7が遠心傾斜しているた め25)，投射面積は 4 ， 5 においては遠心斜面の方が大 となり，6，7 亿扔いては近心斜面が大となり, 結局, 曾列全体としては両斜面の差がみられなくなったと考え られる。

下顎では $\overline{4}, \overline{5}, \overline{6}, \overline{7}$ がすべて近心傾斜している ため ${ }^{25}$ ， 避心斜面の投射面積の方が近心斜面よりも大 きくなったと考えられる．乙の他，雨斜面の差の発現に は, 三角隆線の位置も大いに関係していると思われる.

このことから, 補経学的平面に対し垂直に加わるとさ れる咬合圧 ${ }^{10,111}$ が下額では, 遠心斜面の方により多く 加わると考元られ，歯牙欠損後の残存崡列の近遠心的変 化に対する一つの要因が 示唆されると思われる ${ }^{26,27)}$.

また，咬合圧により下顎触牙は近心にわずかに移動 し，そのため接触点は強固になり食片の圧入が防止さ れ，奥間乳頭ならびに崡槽骨が保護されていることもう かがえる。

II 三角隆線の補経学的平面に対する傾斜角度および 咬頭展開角度

咀嚼機構に扔いて，1個の金属冠より総義圈にいたる まで，咬頭傾斜角度はきわめて重要な要素であり，有歯

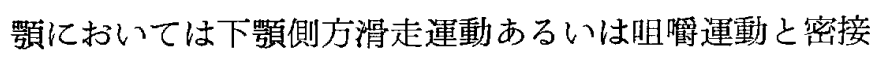

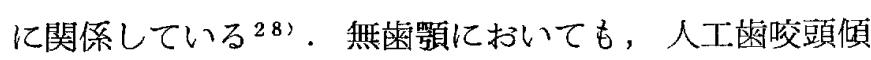
斜角度は下額関節頭の運動路, および切霜路角の影響を

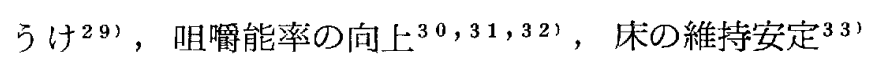
に関与している。

そこで著者は, 正常機能を営んでいる天然歯列におけ る, 三角隆線傾斜角度の標準值を得ることは, その呾嚼 機構の中で占める意義を明確にすることになり，またそ の值は，咬合面形態を回復する際の生物学的基準になる と考え, 測定を行なった。

上下顎とも，左右差ならびに男女差はみられなかっ
た。

機能咬頭と非機能咬頭とにおける，上下顎各咬頭の三 角隆線傾斜角度を比較した。機能咬頭における角度差 は, 男女合わせて平均 $4.4^{\circ}$, 非機能咬頭では $7.5^{\circ}$ とな り，機能咬頭の方が $3.1^{\circ}$ ほど小であった.

矢崎 $\left.(1929)^{8}\right)$ は，咬頭内斜面の咬合平面に対する角 度を，各咬頭近遠心傾斜面の中央において測定している が，左右側同名歯咬頭頂を連結する水平線を咬合平面と している点で，また正中線に直角の方向で測定している 点で, さらに測定の方法も著者とは異なっているが, つ

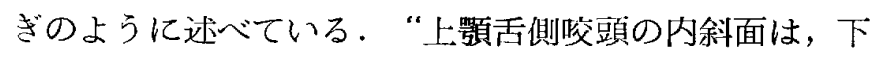
顎煩側峧頭内斜面の角度之一致すままた上顎大日㐘煩側 咬頭と下䫈舌側咬頭との間に僅少の差を生したるは，下 龥舌側においては，生理的にその咬頭が上買舌側咬頭外 斜面に接触せず両者の間に間腺あるがためなり."

著者の測定值では，機能咬頭においては男女とも後方 曰菻部へ向からにしたがってしだいに角度が大となるの に対し, 非機能涗頭においては大曰崡部は小曰歯部より も小さい值を示した。

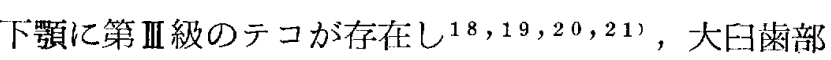
において強い咬合力が加わることを考えると, 機能咬頭 の角度が大田䨑部で大きくなっているのは，大曰䨑部ほ ぞ食物を破砕するのに都合の良い形態をしていると考え られる。

また非機能咬頭における角度が大日柬部で小さくなっ ており，上龥煩側咬頭内斜面と下靧煩側咬頭外斜面，お よび上顎舌側咬頭外斜面と下顎舌側咬頭内斜面とに存在 する間隙は，咀嚼時における食物遁出路の效果を有する ものと思われる. Kraus, et al. $(1969)^{34)}$ は，乙の間 隙は煩や舌の保護にも重要であると述べている。

つぎに三角隆線傾斜角度より咬頭展開角度を求めた。 以上の各咬頭の三角隆線 傾斜角度と咬頭 展開角度と を, 矢崎 $(1929)^{8)}$ の測定值と比較したところ, 測定値 は異なるが，その傾向はほぼ一致した。

これらの測定值は，人工歯排列，および金属冠におけ る咬合面形態回復の際の生物学的基準になると考えられ る. また, 義歯床上の人工歯咬頭傾斜角度は, 最終的に は調節性咬合器上で削合を行なって得られるが，できる だけ削合量を少なくするために，乙の測定值は，人工蒾 製作においても一つの標準になると思われる。

III 歯牙各咬頭頂の補綴学的平面に対する位置.

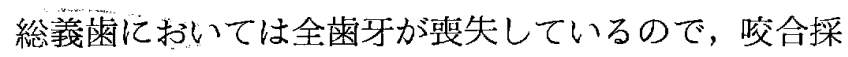
得の際まず咬合平面を再現し，それを基準にして調節彎 曲を決定している．現在のとてろ調節彎曲決定におい 
て，機能的に根拠のある考え方はなく，天然橉列の各棵 牙の位置の平均值を基準としている ${ }^{35}$ のが実情である.

咬合平面の決定方法には Camper 平面, 後臼蒾隆起, 上下䫟歯槽弓の間陌の中央, 舌背, 審美的要素, あるい は頭部X線規格写真に基準を求めるなど多くの方法があ るが36)，Camper は，正常天然菌列の咬合平面は統 計的に Camper 線に平行であると述べており，総義菌 咬合採得時，仮想咬合平面をてのCamper 線に平行に 設定するととが最も普通に行なわれている36,37)。この Camper 線を含屯 Camper 平面，すなわち，補経学的 平面と天然蔽列上の柼合平面との関係については，数多 くの報告がなされている38-49).

著者は，正常者の口腔内石高模型を製作し，各菌牙盿 頭頂と補緅学的平面との位置的関係を, 形状測定器とレ コーダーとを使用し詳細に観察したので，それについて 考察を加えた。

1，あるいは不通る補綴学的平面に平行な平面を考 えた場合，後方 基準点を $6 ，$ あるいは 7 亿置くとすれ ば，最も補緅学的平面に平行となるのは，上頻男性では 1-7MLであり，乙の場合，咬合平面は，補綴学的平 面に対してわずかに後方傾斜を示した．上顎女性では 1 一6 D Lとなり，乙の咬合平面は，補経学的平面に対し 前方傾斜を示した。一方下嚬において，男性では D B ，女性では $\overline{1}-\overline{7} \mathrm{DL}$ となり，この 2 つの咬合平面 は, 補綴学的平面に対していずれも後方に傾斜した。

西田ら（1959）42’は，1と16 ML とを結んだ線が， 30例中70\%に打いて, 補経学的平面に対し後方に傾斜し ていると述べ, 著者の测定值と一致した．また， $\sqrt[1]{ }$ と原 D B とを結んだ線も，77\%において，補緅学的平面に対 し後方傾斜を示すと述へている，著者の测定では男性に おいては一致したが，女性においては前方傾斜を示し t:

鶴島 (1951 $)^{39}$ 'は, $\overline{7} \mathrm{D} \mathrm{B}$ を基点とし, 補経学的平面 に平行な平面を考え，乙の平面より下㖽各柶牙咬頭頂ま での距離を求めている。それによると， 1 と市 D B とを 結ぶ線は, 補経学的平面に対し後方に傾斜している.

つぎに，他の測定法による測定值と比較すると，上原 ら $(1970)^{46)}$ は, 側貌頭部 X線規格写真を応用して, Camper平面から 1， 1 切端の中点まで，および $6 ， \overline{6}$ MBの中点までの距離を測定して，乙の咬合平面は， Camper 平面に対して 後方へ傾斜し, 両者のなす角度 は $2.83^{\circ}$ と報告している.

また，Augsburger (1953） ${ }^{44}$ は，側貌頭部X線規格 写真を使用し, Hartono (1967） ${ }^{49)}$ は, 顔面規格写真を
使用して，顔型を分類して，その各々において咬合平面 と Camper 平面とのなす角度を測定し, 顔型によって 咬合平面とCamper 平面との関係は変化するとしてい る.

試みに，著者の测定值において $1-6 \mathrm{MB}, \overline{1}-6 \mathrm{M}$ Bを結ぶ線を考えてみると，1-6MB男性では，補緅 学的平面に対して後方傾斜を, 女性では逆に前方傾斜を 示した。 $\overline{1}-\overline{6} \mathrm{MB}$ は, 男女とも後方傾斜を示した。

以上のように，咬合平面が Camper 平面に対して， 前方傾斜を示すかあるいは後方傾斜を示すかは, 基準之 する点の設定方法, 被検者の性別, 顔型によって異なっ てくると思われる．また，人工菌列の調節彎曲を付与す る場合, 天然雪列之人工崡列との咬合の構成は基本的に 異なり，天然歯列の位置を完全に模做しても，機能的人 工歯排列が実現されるとは限らない37,501ので，人工歯 排列に扔いては, 天然電列の解剖学的位置を一つの目安 にしながら, 義茵の機能的な要求を满足させていく必要 があると思われる51,52)。

IV 歯冠煩舌的最大幅径扔よび咬頭頂間距離

金属冠においては，咬合王負担能力は，天然歯に比し て著しく劣る13'ので, 支台荬の負担軽減をはかるため, その咬頭頂間距離を天然歯のそれよりも縮少して与える ことが，普通行なわれている7,53-58)。しかし，この 煩舌径の与え方は, 各個人の粜周組織の状態, 支台崡の

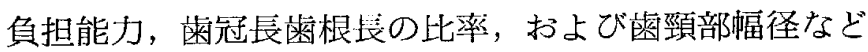
により異なるので，一概には決定できないと思われる． ただどうしても守らなければならない最小限の原則 は，作製すべき咬合面の大きさは，元の菡の咬合面の大 きさより大きくしてはならないということである57).

このためにも，正常者の各畨身における，宷冠最大幅径 と咬頭頂間距離との標準值を，明碓に把握することは意 義があり，その值は咬合面形態回復の生物学的標準にな ると思われる。

以下，測定值について考察を加えた。左在差がみられ なかったので, 左側について男女差の検討を行なったと ころ，上下顎とも有意差がみられた。乙れは，男女にお ける䨑牙の大きさの相違によるものと思われる.

荬冠最大幅径と咬頭頂間距離とについて, 画牙別の大 きさの順序をみると, 最大幅径においては，上額男女と も $6,7 ， 4 ， 5$ ，下㖽男女とも $6 ， 7 ， 5 ， 4$ ，咬頭 頂閤距離においては，上顎男性 $6 ， 7 ， 5 ， 4$ ，女性 6 ， $4 ， 7 ， 5$ ，下顎男女とも $6 ， 7 ， 5 ， 4$ であった。

ここで, 蒾冠最大幅径と咬頭頂間距離の测定值と, 先 に著者が測定した咬頭斜面の補経学的平面に対する投射 


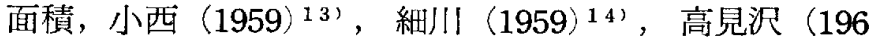
5) ${ }^{15}$ ' の咬合力の值, おょび Tylman $(1970)^{22)}$, 羽賀 ら (1975) ${ }^{231}$ の雨根表面積の值との比較を行なった。投 射面積においては, 全咬合面, 近心斜面, 抢よび遠心斜 面ともその大きさの順序は，上顎男女とも $6 ， 7 ， 4$ ， 5 , 下顎男女とも $6 ， 7 ， 5 ， 4$ ，咬合力に 扔いては $6,7 ， 5 ， 4$, あるいは $6,7 ， 4,5$ ，であり ${ }^{13 ，}$ 14,15)，歯根表面積に扔いては上顎 $6 ， 7 ， 4 ， 5$ ，下

顎 $6,7,5,4$ である22,231.

以上のように, 最大幅径, 咬頭頂間距離, 投射面積, 咬合力，および菌根表面積における大きさの順序はほぼ 一致し, 強い咬合力が加わる窗牙ほど, 雪冠最大幅径と 咬頭頂間距離も大となり，雨牙投射面積と菡根表面積も それにつれて大きくなっている。このととからも，咬合 圧負担に対する，齒牙咬合面形態の合目的性がうかがわ れる。

つぎに，咬頭頂間距離の崡冠最大幅径に対する割合を みると，上澦では，男女とも約 $48 \sim 66 \%$ で，大臼菡部に おいては，遠心が近心よりも小であった，一方，下顝で は約45〜 58\%で，大曰葴部に扔いては，遠心が近心より も大であった. Long $(1968)^{54)}$ は，全部の曰菌の約 80 $\%$ において，咬頭頂間距離は最大幅径の $1 / 2 \sim 2 / 3$ である とし, Kraus, et al. (1969) ${ }^{56)}$ も50〜60\%として, 著 者の測定值とほぼ一致している。

保母（1968） ${ }^{53}$ は，ポンティックについて，咬合面の 面積を縮少する度合いによって，支台隶に加わる圧力は 40\%程度まで減ずることができると述へ，北上（1972） 57によると，Ante は，平均值的に，ポンティックが 1 荬の場合は元の面積の $90 \% ， 2$ 崡の場合は $80 \% ， 3$ 歯 の場合は70\%に縮少するとしている．ナソロジーでは，

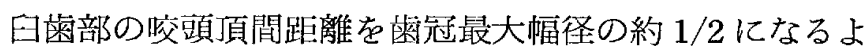
うに作製している55)。

以上，金属冠の咬頭頂間距離の与え方について報告さ れているが，ここに示した著者の測定值も，機能的な咬 合面形態を回復する際の具体的な参考資料になり得ると 思われる。

\section{F 結}

咀嚼機構における，日歯部咬合面形態の意義を明確に するため，また，咬合面形態回復の基準を作製するため 亿, 補経学的平面 (左側鼻翼外側下緣点と雨側外耳導口 下縁点とを含屯平面）を基準にして，正常咬合者40名（ 男性11名，女性29名，平均年䕆18.6才）について，日䨑 部咬合面の形態を観察し以下の結果を得た。測定装置に
は, 形状測定器とXーYレコーダーとを使用した。

1. 補綴学的平面に対する，近心抢よび遠心咬頭斜 面，ならびに咬合面全体の投射面積の大きさの順序は， 上頻では，第 1 大曰歯，第 2 大曰歯，第 1 小曰曾，第 2

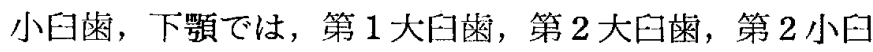
菌，第 1 小曰䨑であった。

2. 上顎田䨑部雪列の近心斜面と遠心斜面との投射面 積に扔いては，危険率 $5 \%$ 以下で，有意差は認められな かった，下䫓においては，有意差が認められ，遠心斜面 の方が近心斜面よりも大であり，その差は男性で 14.40 $\mathrm{mm}^{2}$, 女性で $14.07 \mathrm{~mm}^{2}$ であった。

3. 三角隆線の補綴学的平面に対する傾斜角度は, 機 能咬頭においては，後方臼蒾部へ向かうにしたがって大 きくなった，非機能咬頭においては，大曰歯部は小田歯 部よりも小であった。

4. 咬頭展開角度は，上顎小臼雨部で 103〜 $108^{\circ}$ ，上

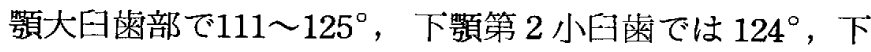
頻大曰荬部では111〜 $127^{\circ}$ であった.

5. 歯牙各咬頭頂の補緅学的平面に対する距離を測定 したところ，最も補綴学的平面に平行となるのは，男性 では，下頷中切歯切縁中央と下顎第 2 大曰歯遠心煩側咬 頭頂とを結ぶ線, 女性では, 下顎中切苳切縁中央と下顎 第 2 大曰崡遠心舌側咬頭頂とを結ぶ線であった。乙の 2 つの咬合平面は，いずれも補綴学的平面に対して，後方 に傾斜していた.

6. 齿冠煩舌的最大幅径と咬頭頂間距離とを測定した ところ, 各粎牙に扔ける，乙れらの大きさの順序は，咬 頭斜面の投射面積の大きさの順序とほぼ一致した．

7. 咬頭頂間距離の最大幅径に対する割合は，上枵で は約48〜66\%，下顎では約45〜 58\%であった。

稿を終わるにあたり，終始懇切な御指導と御校閲を賜 った恩師豊田静夫教授に，謹んで深甚な感謝の意を表わ しまず. そして数多くの御教示, 御鞭撻をいただきまし た，口腔解剖学教室山田博教授ならびに口腔衛生学教室 何窝文夫教授に，心上り御礼申し上げます，また，常に 激励の御言葉をいただきました守川雅男講師に感謝いた しますとともに，御協力をいただきました久保田晴一先 生, 被検者の方々, 補経学教室の皆様に厚く御礼申し 上げます。最後に，多くの御尽力をいただいた营野康幸 氏，徳永文紀氏に御礼申し上げます。

\section{引用 文 献}

1. Granger, E. R. : Functional relations of the 
stomatognathic system, J. A. D. A. $48: 638 \sim 647,1954$.

2. 宮村一弘：上下顎歯列の対向関係に関する研究（咬 頭頂の対向位置について)，日補会誌 $15 ： 322$ $\sim 349,1971$.

3. 杤原博：日本人函牙の㕮耗に関する研究, 熊本医会 誌 $31: 607 \sim 656,1957$.

4. 中尾勝彦 - 田中伐平 - 田中貴信 : 石高歯列模型の寸 法精度, 日補会誌 $15: 178 \sim 185 ， 1971$.

5. J I S 形状および位置の精度の定義および表示・J

I S - B 0621-1972， 1 13, 日本規格協会, 1972 .

6. 市原浩・嘉村高・青木弘之：咬合器装着時の浮き上 りについて, 日補会誌 $13: 221 \sim 222,1969$.

7. 石原寿郎：咬合面形態のあり方, 日雪医師会誌 21 : 207〜214, 1968.

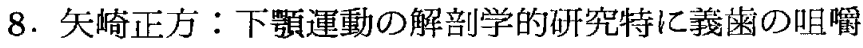
能率に及ぼす関係に就て（その 2 ），歯科学報 $34: 590 \sim 636,1929$.

9. 古屋芳雄・宮坂五一郎：医学統計法（第 5 版）， 48 ５9，金原出版，東京， 1955.

10. Wilson, G. H. : A manual of dental prosthetics ( 4 th and revised ed.) , 33 34, Lea \& Febiger, Philadelphia, 1920.

11. Silverman, M. M. : Occlusion in prosthodontics and in the natural dentition, $73 \sim 76$, Mutual Publishing Co., Washington, 1962.

12. 坪根政治・豊田静夫：総義崡学（前編），56，小 倉, 1970.

13. 小西繁補経に於ける咬合仕に関する研究，日日腔会誌 $8: 427-458,1959$.

14. 細川貞雄：荬牙の咬合力に関する研究, 医学研究 29 : 2915 2923, 1959.

15. 高見沢忠：健常永久䨤の相対咬合力および個歯咬合 力関する研究，日補会誌 $9: 217 \sim 236$, 1965.

16. 三浦不二夫・角田正明：咬合圧（咀嚼圧）に関する 研究, 日歯医師会誌 $7: 293 \sim 298,1954$.

17. 溝上隆男：臼歯部における咀嚼压の時相と負担機構 とに関する研究，䨑科学報 $66: 217 \sim 272$, 1966.

18. 矢崎正方：下顎運動の解剖学的研究特に義菡の咀嚼 能率に及ぼす関係に就て（その1），歯科学報
$34: 103 \sim 161,1929$.

19. 長谷川誠：咀嚼笳作業能借関する補綴学的研究，歯 科学報 $64: 106 \sim 147,1964$.

20. 藤田邦彦：咬合力に関する研究，九州函会誌 $26 ：$ 113 123, 1972.

21. Gosen, A. J. : Mandibular leverage and occlusion, J. P. D. 31, 369 376, 1974.

22. Tylman, S. D. : Theory and practice of crown and fixed partial prosthodontics (bridge) ( 6 th ed.), 192, The C.V.Mosby Co., Saint Louis, 1970.

23. 羽賀通夫 - 腰原好 - 山中喜男 - 他 4 人：永久菌歯根 表面積の研究 (第 2 報)，日補会誌 $18: 250$ $\sim 259,1975$.

24. 鹿島隆雄：勗嚼によって顔面頭蓋に生ずる応力分布 からみた人顔面頭㥺の形態学的研究 (第 1 編)，

凩科学報 $66: 693 \sim 714,1966$.

25. 富士川善彦：天然潾列马における歯冠傾斜角度及び 捻転角度の研究，口病会誌 $25 ： 475 \sim 494$, 1958.

26. 中沢 勇：雨牙欠損後に㧈こる残存函列の位置的変 化，日歯評論 $195: 31 \sim 40,1959$.

27. 妄永博：隣接面接触関係から見た崡列の近遠心方向 の生力学的挙動, 九州齒会誌 $28: 605 \sim 623$, 1975.

28. 藍稔：切菡点部におりる咀嚼運動の解析, 日補会誌 $6: 164 \sim 200,1962$.

29. Boucher, C. O. : Swenson's complete dentures ( 6 th ed.), 211 231, The C.V.Mosby Co., Saint Louis, 1970.

30. Krishan, K. K. and Sham, S. : The effect of denture factors on masticatory performance (part IV) , J. P. D. 15:662 670, 1965.

31. 堌田信式：人工曰菌の咀嚼能率に関する研究（第 2 報)，日補会誌 $17: 401 \sim 421 ， 1974$.

32. 山中喜男: 食品遁出路と咀嚼圧との関係, , 崡科学 報 $71: 966 \sim 994 ， 1971$ 。

33. Ledley, R. S. : The relation of occlusal surfaces to the stability of artificial dentures, J. A. D. A. 48: 508 526, 1954.

34. Kraus, B. S., et al. : Dental anatomy and occlusion, 235, The Williams and Wilkins Co., Baltimore, 1969. 
35. 石原寿郎・長谷川成男・藍稔：下顎運動と咬合器, 212, 日本歯科評論社，東京， 1975 .

36. 青木英夫：仮想咬合平面の諸見解と装置, 補緅臨床

$5: 257 \sim 262,1972$.

37. 坪根政治：カンペル氏平面（所謂補緅学平面）上袋 合床上の想定咬合平面との相対関係設定に関す る一考案, 九州米会誌 $3: 209 \sim 212,1935$.

38. Wilson, G. H. : A manual of dental pros thetics ( 4 th and revised ed.) , $17 \sim 19$,

Lea \& Febiger, Philadelphia, 1920.

39. 鶴島隹岩：荬牙各咬頭頂と補綴学的邗面との位置的

関係に就て, 九州夹会誌 $6: 2 \sim 11,1951$.

40. 矢崎正方：総義歯学, 111 , 而至化学工業株式会社, 東宗， 1958 .

41. 金田重剛：菌牙の排列に関する計測学的研究, 九州 白会誌 $12: 161 \sim 169,1958$.

42. 西田真和・山田登・山下敦：Camper 氏平面と咬 合平面との関係について, 荬科医学 $22: 1904$ $\sim 1908,1959$.

43. 沖野節三: 総義歯補綴学, 234,536 , 永末書店, 京 都, 1964 .

44. Augsburger, R. H. : Occlusal plane relation to facial type, J. P. D. $3: 755 \sim 770$, 1953.

45. Ismail, Y. H. and Bowman, J. F. : Position of the occlusal plane in natural and artificial teeth, J. P. D. $20: 407 \sim 411,1968$.

46. 上原純 - 蕮明江 - 吉岡政雄 - 他 2 人：鼻聴道線の側 貌頭部X線規格写真による研究, 神奈川雪学 $5: 11 \sim 17,1970$.

47. 青木英夫：日本人並びに米国人（白人）青年男女側 貌の頭部 X線規格写真による比較研究, 幽科学 報 $72: 1120 \sim 1161 ， 1972$.

48. 早川巌・安斉隆・打田年実：頭部X線規格写真訓测 法の補経学的忘用に関する研究, 日補会誌 19
: 294 298, 1975.

49. Hartono, R.: The occlusal plane in relation to facial types, J. P. D. $17: 549 \sim 558$, 1967.

50. 沖野節三：総義蒌補経学，467４68, 永末書店, 宗 都, 1964 .

51. Kurth, L. E. : The posterior occlusal plane in full denture construction, J. A. D. A. $27: 85 \sim 93,1940$.

52. Boccaletti, G. : Importance of the occlusal plane and of its relation to the inclination of the condylar path in complete and partial prosthetics, Dental Abstracts 6 : 267, 1961.

53. 保母須弥也：オーラルリハビリテイション，717, 医齿楽出版，東京，1968.

54. Long, A. C. : Acrylic resin veneered crowns : The effect of tooth preparation on crown fabrication and future periodontal health, J. P. D. $19: 370 \sim 380,1968$.

55. Huffman, R. W., et al. : Principles of oc clusion, laboratory and clinical teaching manual, VI-B-11, 12, The Ohio state university, Department of operative dentistry, Ohio, 1969.

56. Kraus, B. S., et al. : Dental anatomy and occlusion, 233, The Williams and Wilkins Co., Baltimore, 1969.

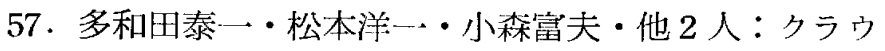
ン・ブリッジの臨休, 123〜135, 医歯薬出版, 東京, 1972 .

58. Glickman, I. : Clinical periodontology ( 4 th ed., Asian ed.) , 937 938, W.B.Saunders Co., Igaku Shoin LTD, Tokyo, 1973. 